\title{
Classification of groundwater suitability for irrigation purposes using a comprehensive approach based on the AHP and GIS techniques in North Kurdufan Province, Sudan
}

\author{
Elsiddig Eldaw ${ }^{1,2} \cdot$ Tao Huang $^{1} \cdot$ Adam Khalifa Mohamed $^{1,2} \cdot$ Yahaya Mahama $^{3}$
}

Received: 9 July 2020 / Accepted: 31 May 2021 / Published online: 26 June 2021

(c) The Author(s) 2021

\begin{abstract}
Deterioration of groundwater quality due to drastic human interventions is rising at an alarming rate particularly in lower- and middle-income countries. Yet, limited research effort has been devoted to monitoring and ascertaining groundwater quality. The present study develops a comprehensive irrigation water quality index (IWQI) for rating water quality of shallow and deep aquifers in North Kurdufan province, Sudan. The new approach is developed to overcome the deficiencies of the existing irrigation indices and coming up with a unified decision for classifying water quality for irrigation purposes. Because of these indices like permeability index (PI), sodium absorption ratio (SAR), etc., depending on specific elements, entirely subjective, as well as the great variations in their results, particularly when classifying water quality. Thus, IWQI is created based on eight indices that are generally used to evaluate irrigation water quality, plus three physicochemical parameters have been proven an impact on water quality. The analytic hierarchy process (AHP) is applied to minimize the subjectivity at assign parameter weights under multiple criteria decision analysis tools (MCDA). The spatial distribution of IWQI agrees with the spatial distribution of the most parameters. The results of our approach reveal that the majority of samples are suitable for irrigation uses for both aquifers except few wells in the confined aquifer. Also, noted that there are very variations in the irrigation indices results for classifying water quality. The comparison result showed that the new index robust, fair calculations and has best classifying of water quality.
\end{abstract}

Keywords FAO $\cdot$ Indices $\cdot$ Irrigation water quality $\cdot$ IWQI $\cdot$ SAHP $\cdot$ Spatial distribution

Elsiddig Eldaw, Adam Khalifa Mohamed, and Yahaya Mahama are a Ph.D. candidate in Southwest Jiaotong University, and Tao Huang is a professor at the Faculty of Geosciences and Environmental Engineering, Southwest Jiaotong University.

Elsiddig Eldaw

siddigeldaw114@yahoo.com

1 Faculty of Geosciences and Environmental Engineering, Southwest Jiaotong University, Chengdu 611756, China

2 College of Water and Environmental Engineering, Sudan University of Sciences and Technology, Khartoum 12304, Sudan

3 School of Transportation and Logistics Engineering, Southwest Jiaotong University, Chengdu 611756, China

\section{Introduction}

Agriculture is a key sector of the Sudanese economy, and thus, attention to groundwater supplies and its monitoring, especially areas where surface water resources are lacking. Since the economy is heavily dependent on agriculture, good quality of water for irrigation is essential. In recent decades, foreign investments in the Agric sector have increased, especially in the northern and western states, which rely mainly on groundwater sources and eventually affecting the quality, as well as quantity of groundwater (Fragaszy and Closas 2016; Eldaw et al. 2020). Furthermore, the population increase, coupled with fast-growing industrial development, is resulting in pollution mainly from human activities to water sources (Nemčić-Jurec et al. 2019). Additionally, secondary infections such as rocks erosion caused by moving water from the excessive abstraction of water from the aquifer (Eldaw et al. 2020). Hence, it has become necessary, though challenging, for both the central and province 
managers to ensure water quality for irrigation (Singh et al. 2009).

Irrigation water quality-related problems include salinity, infiltration, toxicity, and miscellaneous (Ayers and Westcot 1985). These problems mostly arise from total dissolved solids, major cations, and anions of water (Tiwari et al. 2017). A salinity problem happens when the salt stacks in the zone of plant root with a concentration that leads to a loss in productivity (Hao et al. 2017; Merouche et al. 2020). The infiltration problem occurs when water stays on the soil surface or infiltrates to the root zone with an insufficient rate to maintain acceptable yields (Mostafazadeh-Fard et al. 2008). Toxicity problems happen if particular ions (sodium, chloride, or boron) in the soil or water were taken up by the crop and accumulate to high concentrations enough to cause plant growth and hence reduced yields (Singh et al. 2018a). The miscellaneous include problems related to irrigation water quality, which happen with recurrence and eventually resulting in decrease water infiltration rate. Irrigation water quality problems, nevertheless, are overwhelmingly complex, and a set of problems may influence the crop more severely than a single problem. The more complex the problem, the more complicated it is to formulate an appropriate monitoring and assessment program (Singaraja et al. 2015; Chadetrik 2018).

The main concern in developing a comprehensive irrigation water quality index is how to determine the proper weights for various parameters considered. Many researchers who have developed different techniques of water quality indicators (WQI) (Horton 1965; Prati et al. 1971; Dinius 1972; Dee et al. 1973; Walski and Parker 1974; Ribeiro et al. 2002), most of which are designed to evaluate water quality for drinking purpose. Recently, Singh et al. (2018a) have developed an overall index for categorization of irrigation water quality based on Indian standards which set by the Central Pollution Control Board. The guidelines of water for irrigation use proposed by the Food and Agricultural Organization of United Nations (FAO) (Ayers and Westcot 1985) are efficient and have been successfully applied to assess the impact of common constituents in various water sources. Each of these techniques selected the parameter weight values by direct assignment methods. Moreover, there is no consensus on the best way of determining parameter weights, nor is there agreement on a way to give real weight directly. However, in the literature, the scholars have unanimously agreed that the weights computed by applying specific methods are more precise than the weights obtained by the direct weight assignment methods based on the expert opinion of the criteria significance in water quality (Sutadian et al. 2016). So, in the proposed work, to further improve the weights and reduce the possible errors of subjectivity, Saaty's Analytic Hierarchy Process method SAHP (Wu et al. 2017) is employed. Since there are many inter-related parameters used in the assessment of irrigation water quality, it is possible to estimate the appropriate weights for them based on a multiple criteria decision analysis (MCDA) (Sahani 2020). MCDA is applicable to a group decisionmaking environment when it is impractical to formulate criteria evaluation, i.e., it allows qualitative assessment, as well as quantitative evaluation. MCDA is considered a useful tool in resolving inconsistencies associated with the decisionmaking process (Javanbarg et al. 2012; Chadetrik 2018; Murmu et al. 2019). A SAHP is the most used MCDA tool, which uses hierarchical structures to demonstrate the issue and then improves priorities for the alternatives according to the user decision (Sahani 2020).

Several researchers were developed various indicators to evaluate the quality of water destined for irrigation, including electrical conductivity (EC), Sodium absorption ratio (SAR), Kelly's ratio (KR), sodium percentage (Na\%), soluble sodium percentage (SSP), residual sodium carbonate (RSC), magnesium hazards (MH), and permeability index (PI) (Kelley 1941; Richards 1954; Wilcox 1955; Szabolcs 1964; Todd and Mays 1980; Selvam 2015; Singaraja et al. 2015; Sashikkumar et al. 2017). Furthermore, the parameters are entirely subjective and often incapable of precisely determining the quality of irrigation water (Singh et al. 2018a). Additionally, many difficulties and inaccuracies occur when using these parameters individually to classify irrigation water. These approaches depend on specific water contaminants and always faced with high uncertainties in rating water quality particularly when there are major fluctuations in the source water quality. Therefore, in order to address these shortcomings, a comprehensive parametersbased approach is developed to assess the suitability of groundwater for irrigation. Also, our study aims for Identifying the major contaminants which influence the groundwater quality and comparing the results of proposed approach with the existing indexing methods. The proposed irrigation water quality index (IWQI) helps to assess irrigation water quality by converting large datasets into a distinct numerical score by which the quality of irrigation water is described. According to the proposed approach, irrigation water quality can be categorized into five classes: excellent, good, moderate, poor, and very poor in the same manner as supposed by Horton and Singh et al. (Horton 1965; Singh et al. 2018a). Also, the proposed index will assist in assessing the results of individual parameters regarding water pollution status.

\section{Materials and methods}

\section{Study area}

The study is located in the middle part of North Kurdufan Province, Sudan (Fig. 1) and extends between latitudes $\left(12^{\circ}\right.$ 


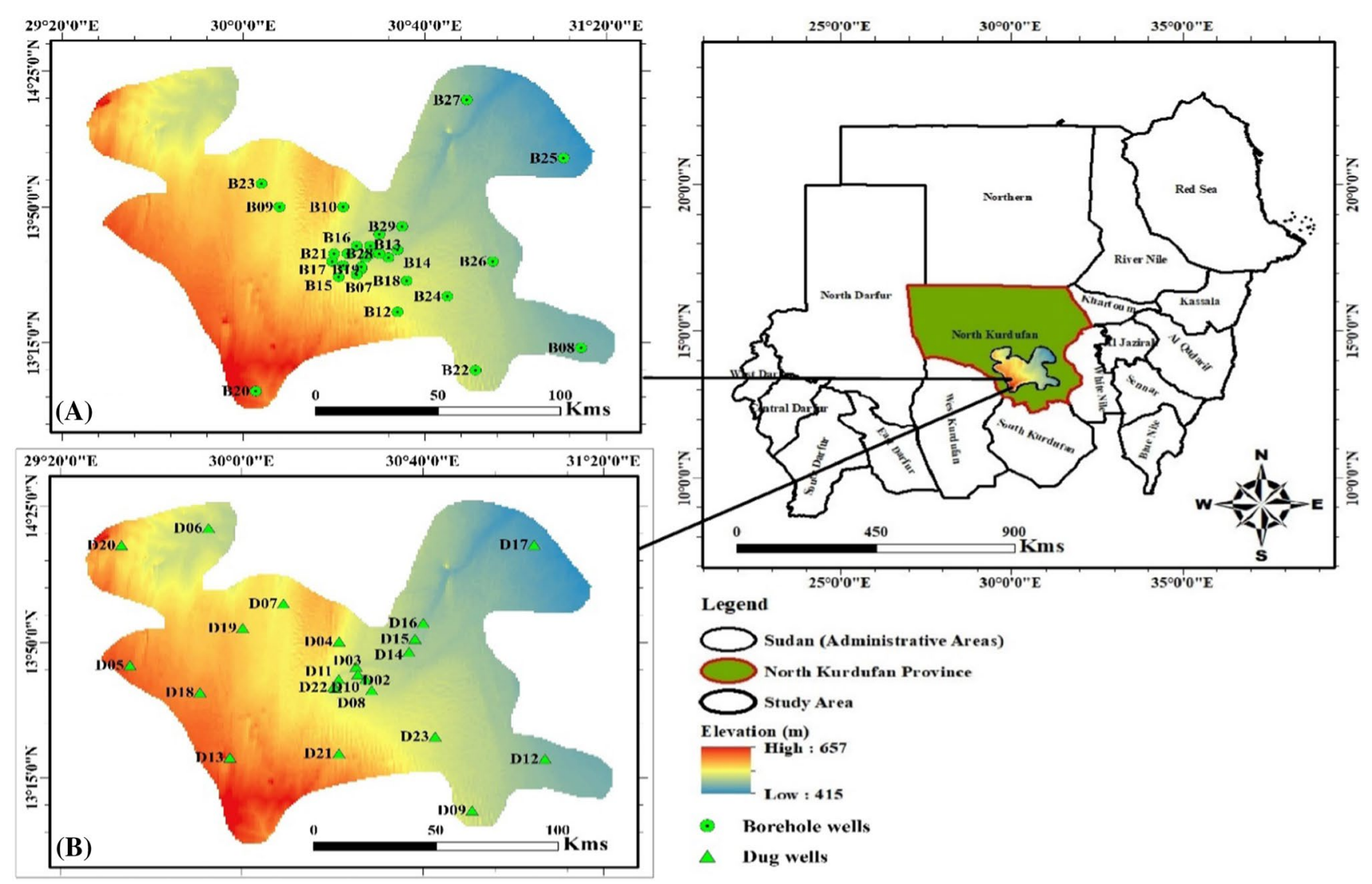

Fig. 1 Location map of the study area along with sampling points (a) confined and (b) unconfined aquifers

$\left.57^{\prime} 48^{\prime \prime}\right)$ to $\left(14^{\circ} 26^{\prime} 32^{\prime \prime}\right) \mathrm{N}$, and longitudes (292 $\left.25^{\prime} 36^{\prime \prime}\right)$ to $\left(31^{\circ} 22^{\prime} 05^{\prime \prime}\right)$ E. The majority of people rely on rain for crop irrigation in the rainy season, while there are few others who use groundwater in the dry season using surface and sprinkler irrigation. Major crops grown in the district are peanuts, millet, corn, hibiscus, tomato, wheat, gum Arabic trees, and palm. The land use and land cover (LULC) of the study area is shown in the Fig. 2. The raining season is between June to October, with $80 \%$ of annual rainfall in July, August, and September. Rains are in the form of showers of variable intensity and duration. According to the 30-year rainfall means, the average annual varies from 100 to $400 \mathrm{~mm}$, with an average precipitation of $312 \mathrm{~mm} /$ year. The average rainfall-runoff coefficient fluctuates between 0.2 and $3.75 \%$. Because of the torrential nature, topography, and soils (i.e., clayey), a large part of the rainwater flows over the ground forming surface runoff. Precipitation flows through numerous wadis towards the impoundments of El Ain and Baggara, and further into Khor Abu Habil. Daily temperatures are very high, varying between $26^{\circ}$ and $40{ }^{\circ} \mathrm{C}$, while a temperature up to $46^{\circ} \mathrm{C}$ is recorded once in a while. The rocks beneath the surficial deposits (Pleistocene to Recent) in the Province consist of the basement complex of Precambrian, Nawa Series (upper Paleozoic), Nubian Series (Mesozoic), and Um Ruwaba Series (Pliocene to Pleistocene) (Whiteman 1971). The general stratigraphic sequence starts from ground surface to depth $49 \mathrm{~m}$, which consist of shallow deposits, fine to medium-grained sand and clayey. Um Ruwaba formations varying from depth $49 \mathrm{~m}$ up to $181 \mathrm{~m}$ are clays, clayey sandy, and sand intercalated. The main aquifer starts from a depth of 181 up to $480 \mathrm{~m}$, which composed of sand and gravel (Whiteman 1971). According to the drilling data, the main aquifer at that location is a continuous media without the existence of separated layers of clayey impermeable. There are two aquifers in the study area: the upper aquifer (shallow) is unconfined with thickness ranging from 30 to $100 \mathrm{~m}$ and 6 to $48 \mathrm{~m}$ in the southwest and northeast part, respectively. The lower aquifer (deeper) is confined, separated by a clay aquiclude layer of $70 \mathrm{~m}$ around Bara town to 150-m-thickness at Um Ruwaba (Abdalla 2006). The average aquifer parameters are found to be as follows: the average transmissivity is $0.528 \mathrm{~m} /$ day, the average hydraulic conductivity is $0.084 \mathrm{~m} /$ day, and the storability is 0.081 . The primary source of aquifer recharge in the study area is the rainfall, which infiltrates and percolates during the rainy season to the subterranean reservoirs, in addition to the groundwater flow from another aquifer (Ali and Whiteley 1981). Observation wells records showed that the water level 
Fig. 2 Map shows the land use and land cover types of the study area

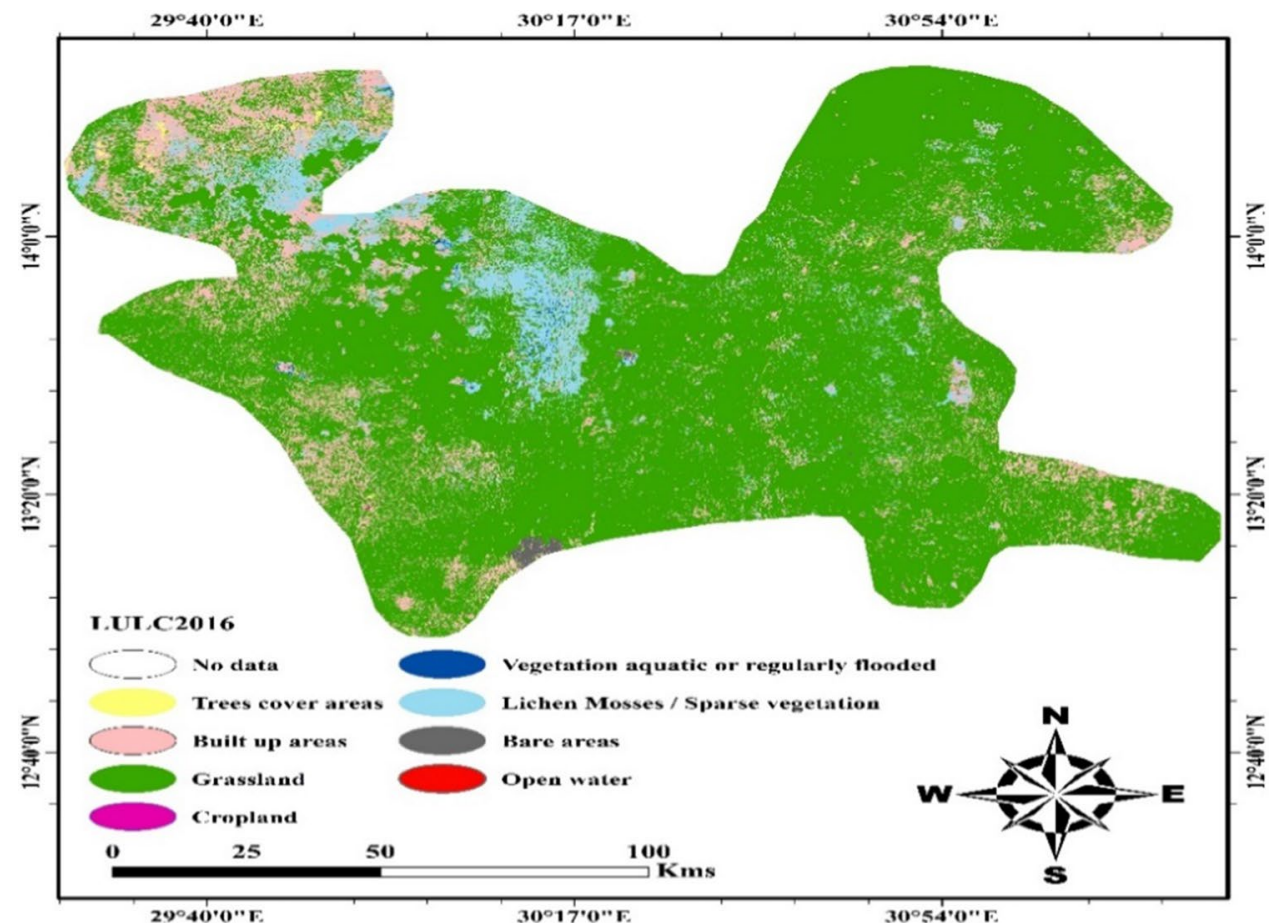

rises annually in the rainy season and decrease in February to April, which represents the dry season.

\section{Sampling and sample preprocessing}

Fifty-two samples of groundwater are obtained from a borehole and dug well in Bara basins, including deep aquifer (29 samples) and shallow aquifer (23 samples). At present, these 52 wells are the only wells available for monitoring and are considered the main source of drinking and irrigation water in the study area. The samples are collected from different locations in a population and agricultural sites of North Kurdufan State. The groundwater sampling is done after 2-3 min of pumping and repeated the samplings three once per well. The samples are preserved in one-liter polyethylene bottles after a good cleaning, labeled before transported and kept at a temperature below $4{ }^{\circ} \mathrm{C}$ until analyzed. The $\mathrm{pH}, \mathrm{EC}$, and TDS parameters were measured in-situ. After delivery to the laboratory, the samples are filtered through a $0.45-\mu \mathrm{m}$ Millipore membrane filter to separate the suspended sediments before analyzing. The data are collected from January to December through 2 years 2017 and 2018 (Fig. 1) and statistically analyzed. It is noted that there was no significant variation in analyzing groundwater samples, so the average value of groundwater quality parameters is considered in this study. The analytical methods adopted in the laboratory to analyse water quality parameters are summarized in Table 1 . The collected samples are analyzed in the College of Water and Environmental Engineering laboratory to determine the concentration of major cations $\left(\mathrm{Ca}^{2+}\right.$,
Table 1 Represents the groundwater quality parameters and their Analytical method in this study

\begin{tabular}{|c|c|c|c|}
\hline Parameters & Acronym & Analytical method & Unit \\
\hline $\mathrm{pH}$ & & $\begin{array}{l}\text { Potentiometry/pH } \\
\text { probe }\end{array}$ & dimensionless \\
\hline $\begin{array}{l}\text { Electrical conduc- } \\
\text { tivity }\end{array}$ & $\mathrm{EC}$ & Conductometry & $\mu \mathrm{mhos} / \mathrm{cm}$ \\
\hline Calcium & $\mathrm{Ca}^{2+}$ & Volumetric method & $\mathrm{mg} / \mathrm{l}$ \\
\hline Magnesium & $\mathrm{Mg}^{2+}$ & Volumetric method & $\mathrm{mg} / \mathrm{l}$ \\
\hline Potassium & $\mathrm{K}^{+}$ & Volumetric method & $\mathrm{mg} / \mathrm{l}$ \\
\hline Sodium & $\mathrm{Na}^{+}$ & Volumetric method & $\mathrm{mg} / \mathrm{l}$ \\
\hline Chloride & $\mathrm{Cl}^{-}$ & Volumetric method & $\mathrm{mg} / \mathrm{l}$ \\
\hline Sulfate & $\mathrm{SO}_{4}{ }^{2-}$ & Volumetric method & $\mathrm{mg} / \mathrm{l}$ \\
\hline Bicarbonate & $\mathrm{HCO}_{3}^{-}$ & Volumetric method & $\mathrm{mg} / \mathrm{l}$ \\
\hline Nitrate & $\mathrm{NO}_{3}^{-}$ & Spectrophotometry & $\mathrm{mg} / \mathrm{l}$ \\
\hline
\end{tabular}

$\mathrm{Mg}^{2+}, \mathrm{Na}^{+}$, and $\left.\mathrm{K}^{+}\right)$and anions $\left(\mathrm{HCO}_{3}{ }^{-}, \mathrm{Cl}^{-}\right.$, and $\left.\mathrm{SO}_{4}{ }^{2-}\right)$, $\mathrm{pH}, \mathrm{EC}, \mathrm{NO}_{3}{ }^{-}$and total dissolved solids (TDS).

\section{Methodology}

In this section, the new approach for irrigation water quality assessment is briefly described in five stages as Fig. 3 .

Step 1 Selection of the important irrigation water quality parameters.

The IWQI is founded on the $\mathrm{pH}$, chloride $(\mathrm{Cl})$, nitrate $\left(\mathrm{NO}_{3}\right),(\mathrm{EC}),(\mathrm{SAR}),(\mathrm{KR}),(\mathrm{Na} \%),(\mathrm{SSP}),(\mathrm{RSC}),(\mathrm{MH})$, and (PI), so, their have been taken into consideration. The parameters have been selected based on their importance 


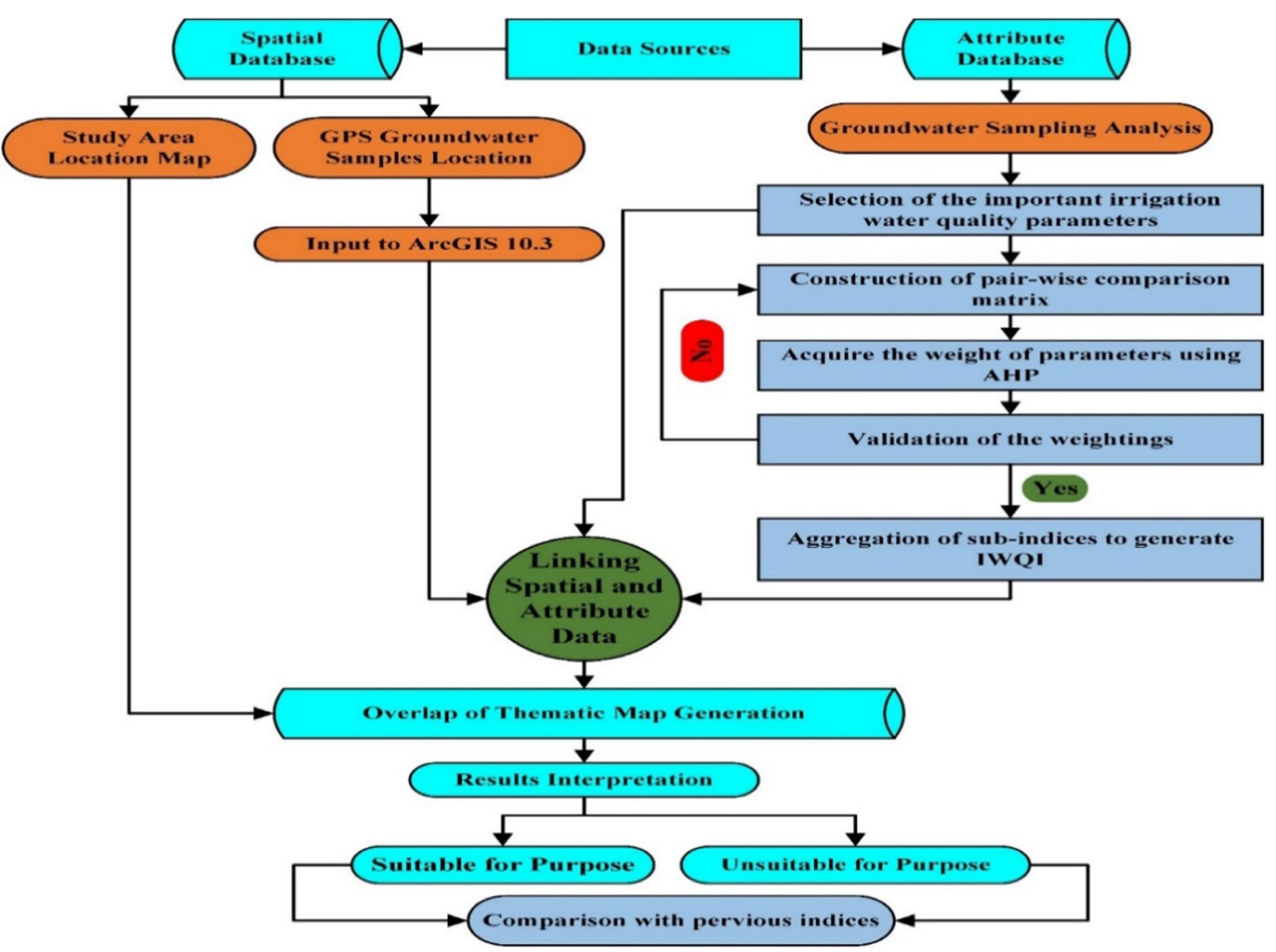

Fig. 3 Methodology flowcharts of the new approach (IWQI)

in irrigation water and expected natural and anthropogenic pollution in the study area.

Step2 Construction of pair-wise comparison matrix.

Selecting weights for the parameters is the most crucial and challenging task, mainly due to the subjectivity resulting from different expert opinions. Naturally, the highest weight is assigned to the parameter that has the most significant influence in the irrigation water quality and vice-versa. We propose to assign weights based on FAO guidelines (Ayers and Westcot 1985), literature review, and judgment of the authors. To establish parameter weights, the pair-wise comparison matrix (PCM) has been generated based on Saaty's 1-9 scale (Table 2) (Saaty 1980). The scale of one means that the importance of the
Table 2 The score of relative importance degree (Saaty 1980)

\begin{tabular}{ll}
\hline Score & Importance \\
\hline 1 & Equal importance \\
3 & Moderate importance \\
5 & Strong importance \\
7 & Very strong importance \\
9 & Extreme importance \\
$2,4,6,8$ & Between two adjacent judgments \\
$(1 / 1$ and $1 / 9)$ & The reciprocal values of 1 to $9(1 / 1$ and $1 / 9)$ are given to the factor \\
& with less importance when compared to another factor more critical \\
& than it \\
\hline
\end{tabular}


factors compared is equal, while the scale of nine indicates the most important factor compared with others (Zhang et al. 2009). The comparison matrix is considered a diagonal matrix, i.e., the diagonal constituents of the matrix are often 1. If the decision measure in the PCM is on the left side of 1 , then we complete the upper triangular matrix with the actual decision value. On the other hand, when the judgment value is found on the right side of one, then the reciprocal value is considered. To complete the cells of the lower triangular matrix, we taken the reciprocal values of the upper diagonal matrix. Table 3 describes a comparison matrix for the contributing parameters.

Step 3 Normalized weight for different parameters.

After preparing a PCM, the normalized weight of different parameters is computed, which is a normalized Eigenvector of the matrix. This vector presents relative weights between the factors compared (Table 4).

Step 4 Consistency check.
A subjective judgment consistency for the parameter weight values can be examined by a consistency ratio (CR), which can be estimated according to Eq. (1).

$C R=\frac{C I}{R I}$

where CI indicates the index of consistency, and RI means a random index of consistency that can be calculated by using the value determined by Saaty's (Saaty 1980). The CI can be estimated using Eq. 2.

$C I=\frac{\lambda_{\max }-1}{n-1}$

where $\lambda_{\max }$ means largest Eigenvalue of the PCM, and $\mathrm{n}$ is the matrix size.

Validating results of weight values: Here, the computed parameter weights of the AHP model are validated to ascertain their degree of consistency, where the maximum consistency threshold is limited to 0.10 . A consistency ratio of
Table 3 Pair-wise comparison matrix

\begin{tabular}{llllllllllll}
\hline & $\mathrm{pH}$ & $\mathrm{Cl}^{-}$ & $\mathrm{NO}_{3}$ & $\mathrm{EC}$ & $\mathrm{SAR}$ & $\mathrm{KR}$ & $\mathrm{Na} \%$ & $\mathrm{SSP}$ & $\mathrm{RSC}$ & $\mathrm{MH}$ & $\mathrm{PI}$ \\
\hline $\mathrm{pH}$ & 1.000 & 0.200 & 0.200 & 0.125 & 0.111 & 0.143 & 0.167 & 0.167 & 0.333 & 0.333 & 0.125 \\
$\mathrm{Cl}^{-}$ & 5.000 & 1.000 & 0.500 & 0.250 & 0.250 & 0.500 & 0.333 & 0.333 & 0.500 & 0.500 & 0.250 \\
$\mathrm{NO}_{3}$ & 5.000 & 2.000 & 1.000 & 0.250 & 0.250 & 0.500 & 0.333 & 0.333 & 3.000 & 0.500 & 0.333 \\
$\mathrm{EC}$ & 9.000 & 4.000 & 4.000 & 1.000 & 1.000 & 3.000 & 3.000 & 3.000 & 4.000 & 6.000 & 2.000 \\
$\mathrm{SAR}$ & 8.000 & 4.000 & 4.000 & 1.000 & 1.000 & 3.000 & 2.000 & 2.000 & 4.000 & 5.000 & 1.000 \\
$\mathrm{KR}$ & 7.000 & 2.000 & 2.000 & 0.333 & 0.333 & 1.000 & 0.500 & 0.500 & 3.000 & 2.000 & 0.333 \\
$\mathrm{Na} \%$ & 6.000 & 3.000 & 3.000 & 0.500 & 0.333 & 2.000 & 1.000 & 1.000 & 5.000 & 3.000 & 0.500 \\
$\mathrm{SSP}$ & 6.000 & 3.000 & 3.000 & 0.500 & 0.333 & 2.000 & 1.000 & 1.000 & 5.000 & 3.000 & 0.500 \\
$\mathrm{RSC}$ & 3.000 & 2.000 & 0.333 & 0.250 & 0.250 & 0.333 & 0.200 & 0.200 & 1.000 & 1.000 & 0.200 \\
$\mathrm{MH}$ & 5.000 & 2.000 & 2.000 & 0.200 & 0.167 & 0.500 & 0.333 & 0.333 & 1.000 & 1.000 & 0.250 \\
$\mathrm{PI}$ & 8.000 & 4.000 & 3.000 & 1.000 & 0.500 & 3.000 & 2.000 & 2.000 & 5.000 & 4.000 & 1.000 \\
\hline
\end{tabular}

Table 4 Represents the final computation of weights and consistency vector using the AHP technique

\begin{tabular}{lllllllllllllll}
\hline & $\mathrm{pH}$ & $\mathrm{Cl}^{-}$ & $\mathrm{NO}_{3}$ & $\mathrm{EC}$ & $\mathrm{SAR}$ & $\mathrm{KR}$ & $\mathrm{Na} \%$ & SSP & $\mathrm{RSC}$ & $\mathrm{MH}$ & $\begin{array}{c}\text { PI } \\
\text { Weight }\end{array}$ & $\begin{array}{l}\text { Consist- } \\
\text { ency } \\
\text { Vector }\end{array}$ \\
\hline $\mathrm{pH}$ & 0.016 & 0.007 & 0.009 & 0.023 & 0.025 & 0.009 & 0.015 & 0.015 & 0.010 & 0.013 & 0.019 & 0.016 & 11.493 \\
$\mathrm{Cl}^{-}$ & 0.079 & 0.037 & 0.022 & 0.046 & 0.055 & 0.031 & 0.031 & 0.031 & 0.016 & 0.019 & 0.039 & 0.041 & 11.296 \\
$\mathrm{NO}_{3}$ & 0.079 & 0.074 & 0.043 & 0.046 & 0.055 & 0.031 & 0.031 & 0.031 & 0.094 & 0.019 & 0.051 & 0.055 & 11.513 \\
$\mathrm{EC}$ & 0.143 & 0.147 & 0.174 & 0.185 & 0.221 & 0.188 & 0.276 & 0.276 & 0.126 & 0.228 & 0.308 & 0.227 & 11.823 \\
$\mathrm{SAR}$ & 0.127 & 0.147 & 0.174 & 0.185 & 0.221 & 0.188 & 0.184 & 0.184 & 0.126 & 0.190 & 0.154 & 0.188 & 11.781 \\
$\mathrm{KR}$ & 0.111 & 0.074 & 0.087 & 0.062 & 0.074 & 0.063 & 0.046 & 0.046 & 0.094 & 0.076 & 0.051 & 0.078 & 11.703 \\
$\mathrm{Na} \%$ & 0.095 & 0.110 & 0.130 & 0.092 & 0.074 & 0.125 & 0.092 & 0.092 & 0.157 & 0.114 & 0.077 & 0.116 & 11.911 \\
$\mathrm{SSP}$ & 0.095 & 0.110 & 0.130 & 0.092 & 0.074 & 0.125 & 0.092 & 0.092 & 0.157 & 0.114 & 0.077 & 0.116 & 11.911 \\
$\mathrm{RSC}$ & 0.048 & 0.074 & 0.014 & 0.046 & 0.055 & 0.021 & 0.018 & 0.018 & 0.031 & 0.038 & 0.031 & 0.039 & 11.381 \\
$\mathrm{MH}$ & 0.079 & 0.074 & 0.087 & 0.037 & 0.037 & 0.031 & 0.031 & 0.031 & 0.031 & 0.038 & 0.039 & 0.051 & 11.643 \\
$\mathrm{PI}$ & 0.127 & 0.147 & 0.130 & 0.185 & 0.110 & 0.188 & 0.184 & 0.184 & 0.157 & 0.152 & 0.154 & 0.172 & 11.828 \\
\hline
\end{tabular}


less than $10 \%(\mathrm{CR} \leq 0.1)$ is considered sufficient for a decision. Otherwise, the comparison matrix will be reconsidered from step two by making some adjustments, and the process repeated until the desired maximum consistency value is achieved. In the present study, the results of $\lambda_{\max }, \mathrm{CI}$ and $\mathrm{RI}$ are determined as $11.662,0.066$, and 1.51 , respectively, and then the CR for the current judgments is calculated as $4.4 \%(<10 \%)$. Consequently, the amount of conflict in the judgment is acceptable (Saaty 1980; Sahani 2020), and the relative weights computed under this percentage $(4.4 \%)$ are consistent for the next use (Table 4).

Step 5 Accumulation of sub-indices to develop a comprehensive index.

An overall irrigation water quality index can be developed using the accumulated weight of the individual parameters to obtain a single combined scale. For this purpose, the new IWQI is generated by modifying an existing approaches (Horton 1965; Singh et al. 2018a). We proposed to aggregate the average weight of all parameters through the following equation:

$I W Q I=\sum_{i=1}^{n} W_{i} Q_{i}$

where the $W_{\mathrm{i}} Q_{\mathrm{i}}$ is the sub-index value of the ith water quality parameter, $W_{\mathrm{i}}$ is the relative weight associated with the ith parameter, and $\mathrm{Q}_{\mathrm{i}}$ is the quality rating scale for each parameter. $Q_{\mathrm{i}}$ is estimated by the ratio of the monitored concentration of $i$ th parameter to its respective permissible value for irrigation uses according to (Kelley 1941; Richards 1954; Wilcox 1955; SZABOLCS 1964; Todd and Mays 1980; Ayers and Westcot 1985; WHO 2011) (Table 5), and the results multiplied by 100 as Eq. 4.

$Q_{i}=\frac{C_{i}}{S_{i}} * 100$

where $C_{i}$ is the measured concentration, calculated by Eqs. (5-11), and $S_{i}$ represents the standard permissible value in milliequivalents per liter (meq/l) except $\mathrm{pH}$ (dimensionless), $\mathrm{Cl}^{-}$and $\mathrm{NO}_{3}{ }^{-}(\mathrm{mg} / \mathrm{l})$ and $\mathrm{EC}(\mu \mathrm{mhos} / \mathrm{cm})$.
Equation (3) is applied to compute the IWQI using the concentration of individual parameters as inputs. The equation suggested here is to limit the index to the range between 0 and 100 . Through the estimated IWQI value, the water quality for agricultural irrigation can be categorized into five classes: excellent water $(<25)$, good water $(26-50)$, moderate water (51-75), poor water (76-100), and very poor or unqualified for irrigation purposes $(>100)$ (Horton 1965; Singh et al. 2018a). The water status corresponding to different IWQI values are pristine quality, acceptable, can be used depending on soil and crop conditions, management of water quality needed and unsuitable, respectively (Singh et al. 2018a).

\section{Data analysis}

Descriptive statistic of physicochemical parameters of groundwater samples $(N=52)$ collected from study area was carried out. Groundwater quality datasets were subjected to two multivariate statistical techniques: pearson correlation coefficient and principal component analysis (PCA). The correlation coefficient is a relative quantitative measure used to determine the direction and size of the relationship between two variables (Karakuş 2020). The correlation coefficient takes a value between +1 and -1 . A correlation coefficient value $(r)$ close to +1 or -1 means a strong correlation between the two variables (Bikundia and Mohan 2014). If the value is equal to zero, indicates that no association. When $(0<r<0.5)$ means a weak correlation between the two variables, $(r>0.7)$ suggests a strong relationship between the variables, and the r-value in range of 0.5 to 0.7 denotes a moderate relationship (Kumar et al. 2006). Moreover, PCA is the most widely statistical criterion used in hydrogeochemical studies. PCA was done to decipher the sources of major ions that affect water quality (Singh et al. 2009, 2015). The data suitability is tested using $\mathrm{KMO}(>0.5)$ and Bartlett's test of sphericity $(p<0.05)$ before implementing PCA, and tests outcome were satisfactory for PCA (Kim et al. 2016). We are selected the principal

Table 5 The values calculated of relative weight $\left(\mathrm{W}_{\mathrm{i}}\right)$ of various irrigation water quality parameters and the permissible standard values notified by to (Kelley 1941; Richards 1954; Wilcox 1955; SZABOLCS 1964; Todd and Mays 1980; Ayers and Westcot 1985; WHO 2011)

\begin{tabular}{llllll}
\hline Parameter & Allowable limit & Weight Factor & Parameter & Allowable limit & Weight factor \\
\hline $\mathrm{pH}$ & 8.5 & 0.016 & Na\% & 60 & 0.116 \\
$\mathrm{Cl}^{-}$ & 354 & 0.041 & SSP & 50 & 0.116 \\
$\mathrm{NO}_{3}$ & 30 & 0.055 & RSC & 2.5 & 0.039 \\
EC & 2000 & 0.227 & MH & 50 & 0.051 \\
$\mathrm{SAR}$ & 26 & 0.188 & PI & 100 & 0.172 \\
KR & 1 & 0.078 & & &
\end{tabular}

All parameter unit in meq/l except for $\mathrm{EC}(\mu \mathrm{mhos} / \mathrm{cm}), \mathrm{NO}_{3}$ in $(\mathrm{mg} / \mathrm{l})$ and $\mathrm{pH}$ (dimensionless) 
components number based on the Eigenvalues that shouldn't less than 1 (Mena-Rivera et al. 2017; Singh et al. 2018b).

\section{Results and Discussions}

\section{Geostatistical Evaluation Analysis}

\section{Pearson Correlation}

Tables 6 and 7 depict the Pearson correlation coefficient required to understand the important relationships among the physicochemical variables of the groundwater samples.

For confined aquifer, the results show that $\mathrm{pH}$ has a very weak correlation with the rest of the variables. This weak correlation may be due to pollution from various origin such as anthropogenic activities. Also, the $\mathrm{pH}$ values are within the permissible limit of WHO and FAO set for irrigation purposes (Ayers and Westcot 1985; Nemčić-Jurec et al.
2019). EC and TDS recorded a strong correlation with $\mathrm{Ca}$ $(r=0.83), \mathrm{TH}(r=0.82), \mathrm{Cl}(r=0.77)$, and $\mathrm{Na}(r=0.71)$ and have a moderate correlation with $\mathrm{Mg}(r=0.59)$ and $\mathrm{SO}_{4}$ $(r=0.54)$. The results here show that $\mathrm{Ca}, \mathrm{Mg}, \mathrm{Na}$, and $\mathrm{Cl}$ ions contribute more to the geochemical process that regulates groundwater quality in the deep aquifer. The $\mathrm{TH}$ is strongly correlated with $\mathrm{Ca}(r=0.98)$ and $\mathrm{Mg}(r=0.77)$ and moderately correlated with $\mathrm{Cl}(\mathrm{r}=0.68)$ and $\mathrm{SO}_{4}(r=0.57)$. The strong correlation between the water hardness property and cations ( $\mathrm{Ca}$ and $\mathrm{Mg}$ ) and the moderate correlation with anions $\left(\mathrm{Cl}\right.$ and $\left.\mathrm{SO}_{4}\right)$ indicate that the hardness in groundwater samples of the confined aquifer is mainly resulting from the sulfate/chloride salts of calcium and magnesium, and it is considered permanent hardness. A strong positive correlation is also noticed between $\mathrm{Cl}-\mathrm{SO}_{4}(r=0.74), \mathrm{Na}-\mathrm{SO}_{4}$ $(r=0.73), \mathrm{Ca}-\mathrm{Cl}(r=0.70)$, and $\mathrm{Na}-\mathrm{Cl}(r=0.70)$. A moderate correlation is also observed between $\mathrm{Ca}-\mathrm{Mg}(r=0.61)$, $\mathrm{Na}-\mathrm{HCO}_{3}(r=0.61)$, and $\mathrm{Ca}-\mathrm{SO}_{4}(r=0.59)$. The moderate correlation between $\mathrm{SO}_{4}$ with $\mathrm{Ca}$ and $\mathrm{Mg}$ emphasizes the
Table 6 Represents the correlation matrix results (Pearson) of physicochemical parameters in the studied deep aquifer water samples
Table 7 Represents the correlation matrix results (Pearson) of physicochemical parameters in the studied shallow aquifer water samples

\begin{tabular}{|c|c|c|c|c|c|c|c|c|c|c|c|c|}
\hline & $\mathrm{pH}$ & EC & TDS & $\mathrm{Ca}^{2+}$ & $\mathrm{Mg}^{2+}$ & $\mathrm{Na}^{+}$ & $\mathrm{K}^{+}$ & $\mathrm{HCO}_{3}^{-}$ & $\mathrm{SO}_{4}{ }^{2-}$ & $\mathrm{Cl}^{-}$ & $\mathrm{NO}_{3}^{-}$ & $\overline{\mathrm{TH}}$ \\
\hline $\mathrm{pH}$ & 1 & & & & & & & & & & & \\
\hline EC & 0.02 & 1 & & & & & & & & & & \\
\hline TDS & 0.02 & $1.00^{* *}$ & 1 & & & & & & & & & \\
\hline $\mathrm{Ca}^{2+}$ & 0.09 & $0.83^{* *}$ & $0.83 * *$ & 1 & & & & & & & & \\
\hline $\mathrm{Mg}^{2+}$ & 0.17 & $0.59 * *$ & $0.59 * *$ & $0.61 * *$ & 1 & & & & & & & \\
\hline $\mathrm{Na}^{+}$ & 0.12 & $0.71 * *$ & $0.71 * *$ & $0.47 * *$ & $0.39 *$ & 1 & & & & & & \\
\hline $\mathrm{K}^{+}$ & 0.03 & -0.09 & -0.09 & -0.15 & 0.00 & -0.15 & 1 & & & & & \\
\hline $\mathrm{HCO}_{3}^{-}$ & 0.28 & 0.23 & 0.23 & 0.13 & 0.15 & $0.61 * *$ & 0.04 & 1 & & & & \\
\hline $\mathrm{SO}_{4}^{2-}$ & 0.02 & $0.54 * *$ & $0.54 * *$ & $0.59 * *$ & $0.42 *$ & $0.73 * *$ & -0.17 & 0.34 & 1 & & & \\
\hline $\mathrm{Cl}^{-}$ & -0.21 & $0.77 * *$ & $0.77 * *$ & $0.70 * *$ & $0.45^{*}$ & $0.70 * *$ & -0.08 & 0.28 & $0.74 * *$ & 1 & & \\
\hline $\mathrm{NO}_{3}^{-}$ & -0.07 & 0.09 & 0.09 & 0.22 & 0.06 & 0.09 & 0.00 & -0.08 & 0.21 & 0.19 & 1 & \\
\hline $\mathrm{TH}$ & 0.12 & $0.82 * *$ & $0.82 * *$ & $0.98 * *$ & $0.77 * *$ & $0.46^{*}$ & -0.11 & 0.12 & $0.57 * *$ & $0.68 * *$ & 0.20 & 1 \\
\hline
\end{tabular}

$*$, **Correlation is significant at the 0.05 and 0.001 level (2-tailed), respectively

\begin{tabular}{|c|c|c|c|c|c|c|c|c|c|c|c|c|}
\hline & $\mathrm{pH}$ & EC & TDS & $\mathrm{Ca}^{2+}$ & $\mathrm{Mg}^{2+}$ & $\mathrm{Na}^{+}$ & $\mathrm{K}^{+}$ & $\mathrm{HCO}_{3}^{-}$ & $\mathrm{SO}_{4}{ }^{2-}$ & $\mathrm{Cl}^{-}$ & $\mathrm{NO}_{3}^{-}$ & $\mathrm{TH}$ \\
\hline $\mathrm{pH}$ & 1 & & & & & & & & & & & \\
\hline EC & -0.26 & 1 & & & & & & & & & & \\
\hline TDS & -0.26 & $1 * *$ & 1 & & & & & & & & & \\
\hline $\mathrm{Ca}^{2+}$ & -0.05 & $0.56^{* *}$ & $0.56^{* *}$ & 1 & & & & & & & & \\
\hline $\mathrm{Mg}^{2+}$ & -0.12 & $0.73 * *$ & $0.73 * *$ & $0.82 * *$ & 1 & & & & & & & \\
\hline $\mathrm{Na}^{+}$ & -0.38 & $0.65 * *$ & $0.65^{* *}$ & 0.38 & $0.46^{*}$ & 1 & & & & & & \\
\hline $\mathrm{K}^{+}$ & -0.02 & 0.06 & 0.06 & 0.23 & 0.06 & -0.07 & 1 & & & & & \\
\hline $\mathrm{HCO}_{3}^{-}$ & -0.32 & $0.88 * *$ & $0.88^{* *}$ & 0.39 & $0.54 * *$ & $0.58 * *$ & 0.12 & 1 & & & & \\
\hline $\mathrm{SO}_{4}{ }^{2-}$ & $-0.42 *$ & $0.87 * *$ & $0.87 * *$ & 0.38 & $0.48^{*}$ & $0.57 * *$ & -0.06 & $0.82 * *$ & 1 & & & \\
\hline $\mathrm{Cl}^{-}$ & -0.32 & $0.89 * *$ & $0.89 * *$ & $0.44 *$ & $0.64 * *$ & $0.78 * *$ & 0.04 & $0.82 * *$ & $0.69 * *$ & 1 & & \\
\hline $\mathrm{NO}_{3}^{-}$ & 0.05 & $0.62 * *$ & $0.62 * *$ & $0.70 * *$ & $0.74 * *$ & 0.25 & 0.30 & 0.34 & 0.35 & 0.48 & 1 & \\
\hline $\mathrm{TH}$ & -0.09 & $0.66^{* *}$ & $0.66^{* *}$ & $0.97 * *$ & $0.94 * *$ & $0.43^{*}$ & 0.17 & $0.47 *$ & $0.44 *$ & $0.55^{* *}$ & $0.75 * *$ & 1 \\
\hline
\end{tabular}

*, ***Correlation is significant at the 0.05 and 0.001 level (2-tailed), respectively 
presence of limy magnesium materials in the groundwater of confined aquifer (Singh et al. 2011).

The correlation coefficient results of groundwater parameters for the shallow aquifer is displayed in Table 7 . $\mathrm{pH}$ shows a weak negative correlation with $\mathrm{SO}_{4}(r=-0.42)$ and very poor correlation with the rest of the variables. The high positive association between EC and TDS observed indicates that the EC is considered a measure of TDS in the groundwater samples. EC and TDS show a strong positive correlation with $\mathrm{Cl}(r=0.89), \mathrm{HCO}_{3}(r=0.88), \mathrm{SO}_{4}$ $(r=0.87)$, and $\mathrm{Mg}(r=0.73)$ and moderate correlation with $\mathrm{TH}(r=0.66), \mathrm{Na}(r=0.65), \mathrm{NO}_{3}(\mathrm{r}=0.62)$, and $\mathrm{Ca}$ $(\mathrm{r}=0.56)$. TH is strongly correlated with $\mathrm{Ca}(r=0.97), \mathrm{Mg}$ $(\mathrm{r}=0.94)$, and $\mathrm{NO}_{3}(r=0.75)$, moderately with $\mathrm{Cl}(r=0.55)$ and a fairly moderate with $\mathrm{HCO}_{3}(r=0.47), \mathrm{SO}_{4}(r=0.44)$, and $\mathrm{Na}(r=0.43)$. A strong high correlation between $\mathrm{TH}$ with cations $(\mathrm{Ca}$ and $\mathrm{Mg}$ ) plus nitrate and weak correlation with the bicarbonate and chloride indicate that the hardness in groundwater of an unconfined aquifer is resulting from the nitrate of the calcium and magnesium and is permanent hardness. $\mathrm{NO}_{3}$ is strongly correlated with $\mathrm{Mg}(r=0.74)$, and $\mathrm{Ca}(r=0.70)$, and weakly with $\mathrm{Cl}(r=0.48)$. Strong positive correlations are also showed between $\mathrm{Ca}-\mathrm{Mg}(\mathrm{r}=0.82)$, $\mathrm{Na}-\mathrm{Cl}(r=0.78), \mathrm{HCO}_{3}$ with $\left(\mathrm{SO}_{4}\right.$ and $\left.\mathrm{Cl}\right)(r=0.82$ for both). Also, a moderate relationship is observed between $\mathrm{SO}_{4}-\mathrm{Cl}(r=0.69), \mathrm{Mg}-\mathrm{Cl}(r=0.64), \mathrm{Na}-\mathrm{HCO}_{3}(r=0.58)$, $\mathrm{Na}-\mathrm{SO}_{4}(r=0.57)$, and $\mathrm{Mg}-\mathrm{HCO}_{3}(r=0.54)$. The moderate correlation between $\mathrm{SO}_{4}$ and $(\mathrm{Ca}$ and $\mathrm{Mg})$ emphasizes the presence of limy magnesium materials in the North Kurdufan Province (Singh et al. 2011). A positive relationship between sulfate and most elements suggests that the source of sulfate is rocky weathering (Tiwari et al. 2017). Also, the low ratios of $\mathrm{Na}^{+} / \mathrm{Cl}^{-}(<1.0)$ with a strong positive correlation suggest that the source is halite and is mostly derived by rock weathering (Tiwari et al. 2017).

\section{Principal Component Analysis (PCA)}

PCA is applied to determine and confirm what the major ions related to groundwater pollution (Singh et al. 2018b). Our results illustrate that the percentage of the total variance of $68 \%$ and $83 \%$ of 10 original variables for the confined and unconfined aquifers, respectively. The principal component matrix is shown in the Table 8. The scree plot given in Fig. 4 demonstrates the eigenvalue for each principal component. An obvious change in slope can be observed in the scree plot after the third component.

For confined aquifer, three components exhibit for 43, 14, and 11 percent of the total variance (Fig. 4). From the Table 8 , it is observed that PC-I is statistically dominant, contributes $43 \%$ of the total variance, and depicts an extreme positive loading of TDS, $\mathrm{Cl}^{-}, \mathrm{Na}^{+}, \mathrm{Ca}^{2+}, \mathrm{SO}_{4}{ }^{2-}$, and $\mathrm{Mg}^{2+}$. PC-I in the confined aquifer is clearly a lithogenic component, which interprets the dissolution of silicates. Similarly, PC-2 accounts for $14 \%$ of the total variance. It has strong positive load factor on the variables of $\mathrm{pH}, \mathrm{HCO}_{3}{ }^{-}$, suggesting that it is the inclusive measurement of alkalization of the groundwater. Similarly, PC-3 has positive load factor on $\mathrm{Mg}^{2+}$ and $\mathrm{K}^{+}$.

For unconfined aquifer, three components exhibit for 54, 16, and 13 percent of the total variance (Fig. 4). From the Table 8 , it is observed that the PC-I contributes $54 \%$ of the total variance and depicts very strong positive loading of $\mathrm{SO}_{4}{ }^{2-}, \mathrm{Cl}^{-}$, TDS, $\mathrm{HCO}_{3}{ }^{-}$, and $\mathrm{Na}^{+}$. It indicates that these parameters which control the chemistry of groundwater by weathering of silicate with limited contribution from anthropogenic activities. Similarly, PC-2 accounts for $16 \%$ of the total variance and shows strong loading of $\mathrm{NO}_{3}^{-}, \mathrm{Ca}^{2+}$, and $\mathrm{Mg}^{2+}$. This component may be concerned with the anthropogenic sources, resulting from domestic and recharge from the agricultural land. Similarly, PC-3 accounts for $13 \%$ of the
Table 8 Results of the principal component analysis (PCA) of groundwater parameters

\begin{tabular}{|c|c|c|c|c|c|c|c|c|}
\hline \multirow[t]{2}{*}{ Variables } & \multicolumn{4}{|c|}{ Confined } & \multicolumn{4}{|c|}{ Unconfined } \\
\hline & PC-I & PC-II & PC-III & Communality & PC-I & PC-II & PC-III & Communality \\
\hline $\mathrm{pH}$ & 0.074 & 0.701 & -0.042 & 0.925 & -0.346 & 0.653 & 0.324 & 0.625 \\
\hline TDS & 0.883 & -0.095 & 0.216 & 0.837 & 0.967 & -0.034 & 0.108 & 0.947 \\
\hline $\mathrm{Ca}^{2+}$ & 0.836 & -0.220 & 0.203 & 0.874 & 0.688 & 0.545 & -0.129 & 0.787 \\
\hline $\mathrm{Mg}^{2+}$ & 0.648 & 0.103 & 0.514 & 0.762 & 0.813 & 0.425 & -0.151 & 0.864 \\
\hline $\mathrm{Na}^{+}$ & 0.845 & 0.247 & -0.264 & 0.885 & 0.730 & -0.335 & -0.237 & 0.702 \\
\hline $\mathrm{K}^{+}$ & -0.164 & 0.305 & 0.563 & 0.543 & 0.120 & 0.133 & 0.930 & 0.897 \\
\hline $\mathrm{HCO}_{3}^{-}$ & 0.434 & 0.676 & -0.365 & 0.844 & 0.855 & -0.247 & 0.307 & 0.886 \\
\hline $\mathrm{SO}_{4}^{2-}$ & 0.820 & -0.013 & -0.176 & 0.720 & 0.827 & -0.295 & 0.265 & 0.842 \\
\hline $\mathrm{Cl}^{-}$ & 0.877 & -0.205 & 0.040 & 0.891 & 0.898 & -0.185 & -0.060 & 0.845 \\
\hline $\mathrm{NO}_{3}^{-}$ & 0.254 & -0.441 & -0.425 & 0.560 & 0.651 & -0.598 & 0.225 & 0.831 \\
\hline Eigenvalues & 4.341 & 1.406 & 1.088 & & 5.382 & 1.574 & 1.296 & \\
\hline$\%$ of variance & 43 & 14 & 11 & & 54 & 16 & 13 & \\
\hline$\%$ of cumulative & 43 & 57 & 68 & & 54 & 70 & 83 & \\
\hline
\end{tabular}



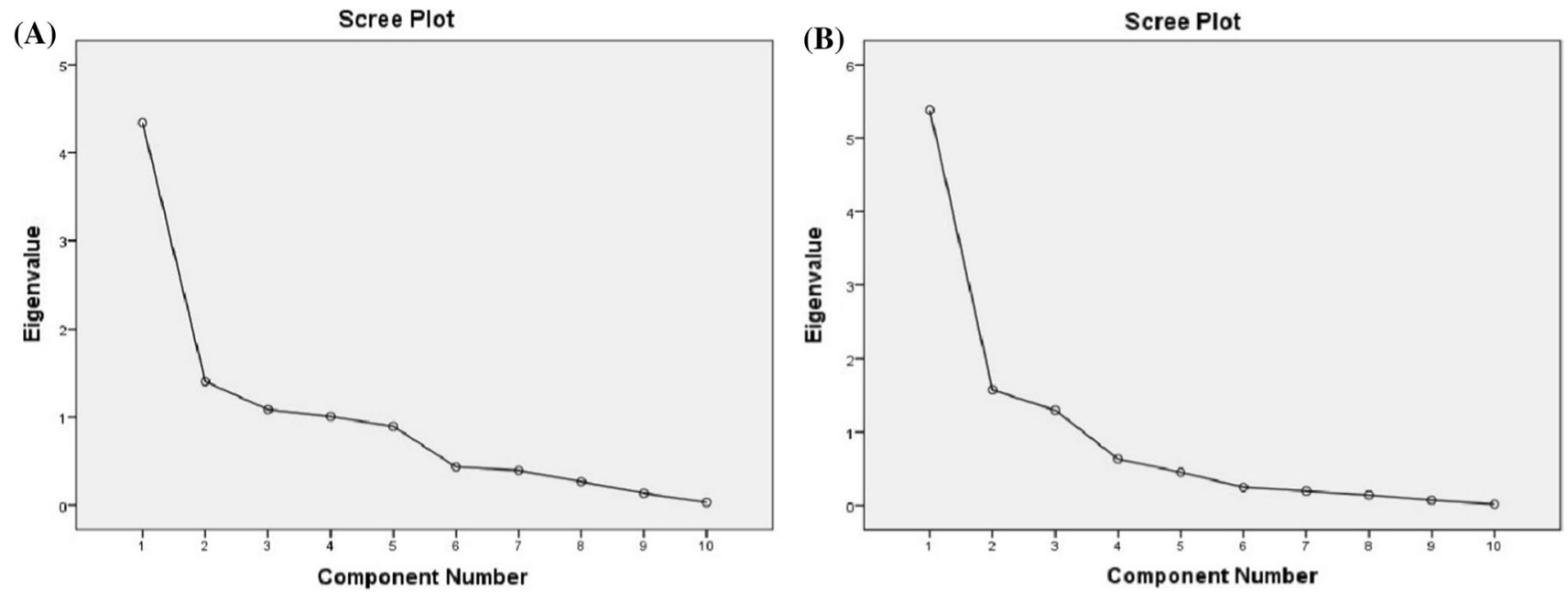

Fig. 4 Scree plot of the eigenvalue for each component (a) confined and (b) unconfined aquifers

total variance. It has strong positive load factor on the variable of $\mathrm{K}^{+}$, indicating that the natural weathering controls the groundwater system.

\section{Variation and Spatial Distribution of the Parameters}

Statistical analyses revealed that the seasonality data variations have an insignificant trend, so, in this study, the average value of groundwater quality parameters is considered. Statistical analysis is regarded as an excellent tool to analyse large amounts of data and report general trends. Accordingly, the statistical summary of physicochemical parameters $\left(\mathrm{pH}, \mathrm{Cl}\right.$, and $\mathrm{NO}_{3}$ ) and irrigation indices (EC, SAR, $\mathrm{KR}, \mathrm{Na} \%$, SSP, RSC, MH, and PI) of the groundwater is displayed in Table 9, along with minimum (Min), maximum (Max), mean, and standard deviation (SD) measures. The detailed discussion of statistical measures is provided together with ArcGIS mapping in the following section for a comprehensive study of spatial variability and the concentrations of various parameters in both aquifers.

\section{Physicochemical Parameters $\left(\mathrm{pH}, \mathrm{Cl}, \mathrm{NO}_{3}\right)$}

The $\mathrm{pH}$ scale is used to determine the acidity or alkalinity of water. The scale ranging from 0 to 14 . If the water sample has a $\mathrm{pH}$ of less than seven considered acidity water, while considered alkalinity water when the $\mathrm{pH}$ above 7 (Merouche et al. 2020). The groundwater quality of confined and unconfined aquifers has relatively high $\mathrm{pH}$ in the range of 6.9 to 9.1 and 8 to 9.4 with an average of 8.06 and 8.58, respectively, compared to the standard (Ayers and Westcot 1985), which shows that the water is slightly basicity in nature, while only one sample B15 has neutral $\mathrm{pH}$ (Figs. 5 and 6). The relatively high $\mathrm{pH}$ values reveal that the groundwater tendency to dissolve the soil limestone resulting in the release of sodium and calcium, which progressively increases $\mathrm{pH}$ value in groundwater (Venkatramanan et al. 2017). $\mathrm{Cl}$ values in confined and unconfined aquifers range between 10.6 to 258.8 and 12.05 to 124.07 , respectively. According to the chloride concentration, all samples in both aquifers are acceptable for irrigation use (Ayers and Westcot 1985). The minimum and maximum levels of $\mathrm{NO}_{3}$ are $3-89.1$ and $1.86-47.33 \mathrm{mg} / \mathrm{l}$ in confined and unconfined aquifers, respectively. Regarding nitrate; the statistical findings indicate that $58.62 \%$ of groundwater samples in the confined aquifer are suitable for irrigation purposes, and $41.38 \%$ samples are questionable, while all samples of the unconfined aquifer are fit for irrigation use except the samples (D06, D15, and D21) (Ayers and Westcot 1985). It is seen from Fig. 3 that the sites D15 and D21 lie in the middle part and D06 in the northwestern part of the study area. The slight high concentration of nitrates in the study area may be explained to contamination from agricultural activities and injection wells used to drain the wastewater, which increases nitrate loading into the aquifer.

\section{Irrigation Water Quality Indices}

Many parameters are estimated to ensure reliable results for the quality of irrigation water of the aquifers. These parameters include EC, SAR, KR, Na\%, SSP, RSC, MH, and PI. The parameters are mathematical expressions that convert water quality concentrations component into a numeric measure to describe the irrigation water quality. Figures 7 and 8 present the GIS interpolation maps of spatial distribution for selected irrigation water quality parameters. The results are calculated based on Eqs. (5-11). Table 10 shows 

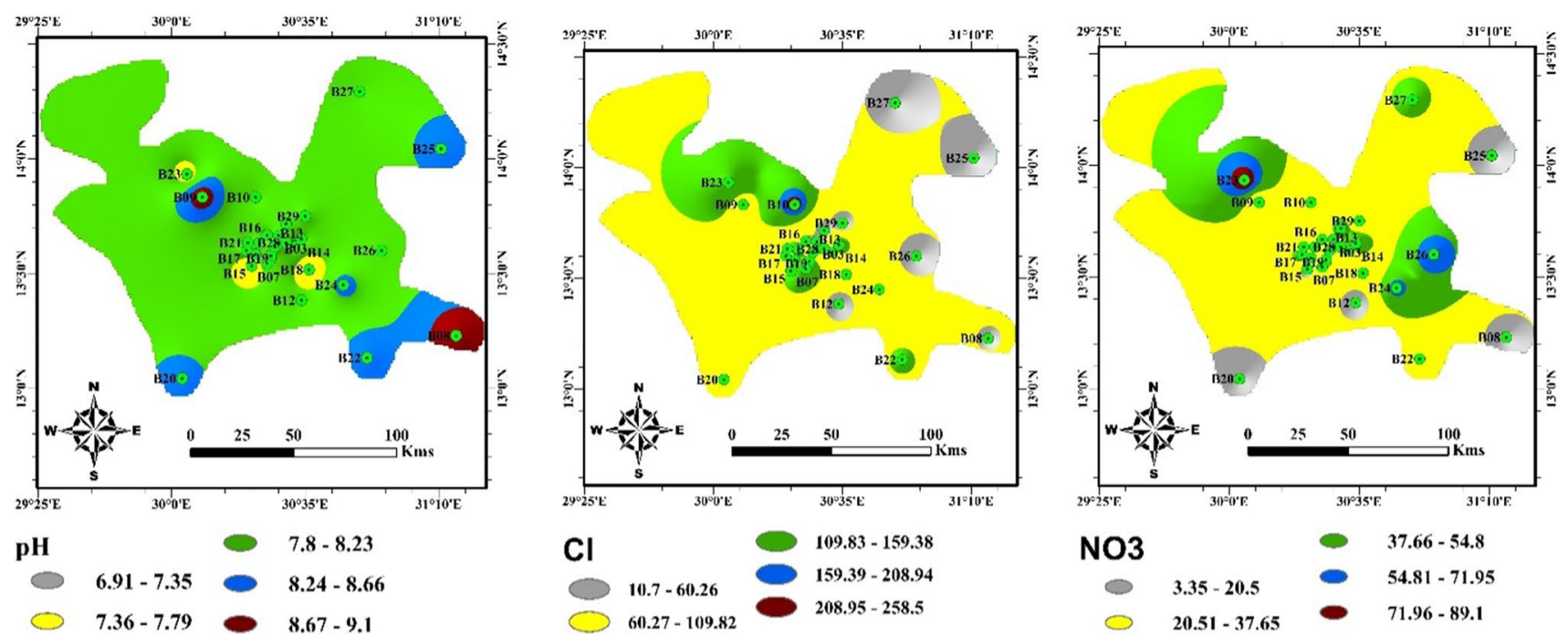

Fig. 5 Spatial distribution of GIS interpolation maps of the $\mathrm{pH}, \mathrm{Cl}$, and $\mathrm{NO}_{3}$ parameters in the confined aquifer
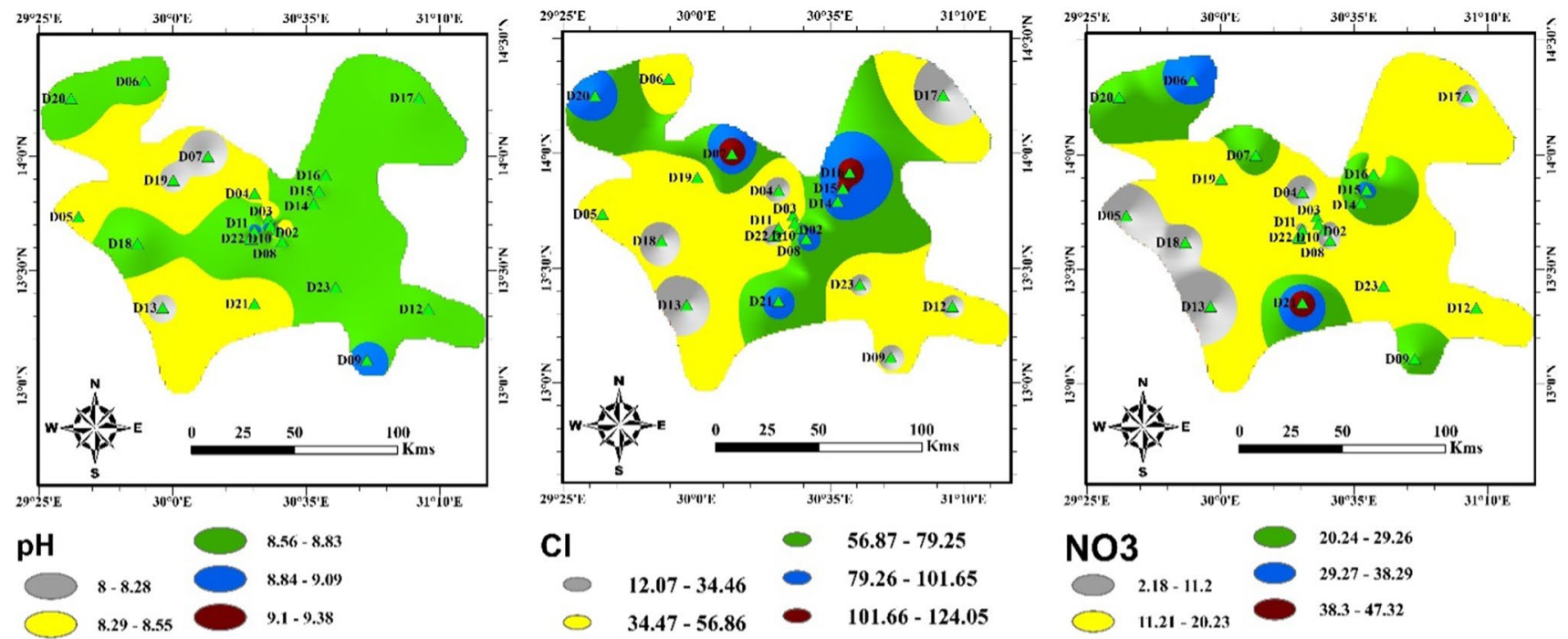

Fig. 6 Spatial distribution of GIS interpolation maps of the $\mathrm{pH}, \mathrm{Cl}$, and $\mathrm{NO}_{3}$ parameters in an unconfined aquifer

the standard limit of these parameters for the comparative analysis.

Electrical Conductivity EC has essential impacts on the soil structure and normal crop growth when irrigation water contains high salinity (Nematollahi et al. 2016). The measured EC values for the confined and unconfined aquifers vary between 170 to 4400 and 144 to $2519 \mu \mathrm{mhos} / \mathrm{cm}$, respectively. Concerning EC, the Wilcox classification (Wilcox 1955). showed that all groundwater samples are tolerable for irrigation use except the sample B10 in the confined aquifer. It is observed from Fig. 7 that the B10 sample lies in the middle part of the study area. The high concentration of EC may be attributed to either by the rocks weathering or the use of artificial fertilizers.

Sodium Adsorption Ratio Sodium adsorption ratio (SAR) is defined as in the Eq. (5), according to Richards (Richards 1954), where all ions unit in milliequivalent per liter (meq/L).

$$
\mathrm{SAR}=\frac{\mathrm{Na}^{+}}{\sqrt{\mathrm{Ca}^{2+}+\mathrm{Mg}^{2+}}}
$$



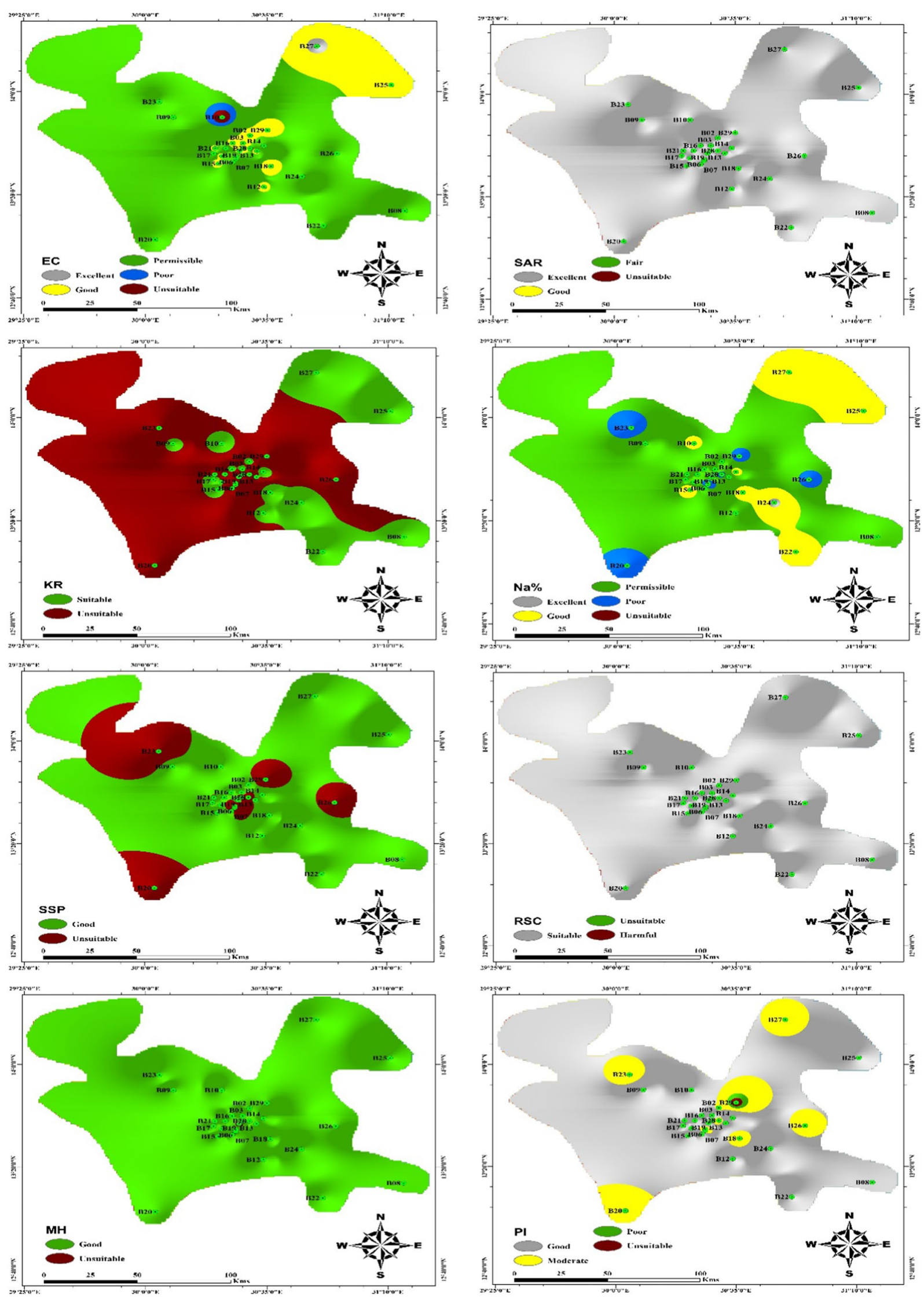
4Fig. 7 Spatial distribution of GIS interpolation maps of the irrigation quality evaluation indices results (EC, SAR, KR, Na\%, SSP, RSC, $\mathrm{MH}$, and PI) in confined aquifer

SAR assesses the potential risk of salinization related to water use. It determines the hazard degree on the plants that are resulting from sodium and alkalinity (Todd and Mays 1980). From Figs. 7 and 8, it is observed that the groundwater quality in both aquifers is suitable for irrigation based on the SAR index.

Kelly's Ratio Kelly's ratio (KR) is defined as in the Eq. 6 (Kelley 1941), where all ions unit in milliequivalent per liter (meq/L).

$\mathrm{KR}=\frac{\mathrm{Na}^{+}}{\mathrm{Ca}^{2+}+\mathrm{Mg}^{2+}}$

$\mathrm{KR}$ is another method to classify water for irrigation use. It is calculated by taking into account the ratio of the sodium ion to the ions of calcium and magnesium. Based on the KR value, about $68.97 \%$ and $86.96 \%$ of samples in confined and unconfined aquifers, respectively, are fit for irrigation use (Figs. 7 and 8). It is also observed that the KR of the confined aquifer is high in the western and southwestern parts, which indicates that the water is unfit for irrigation purposes.

Sodium Percentage Sodium percentage $(\mathrm{Na} \%)$ is defined as in the Eq. 7 (Wilcox 1955), where all ions unit in milliequivalent per liter (meq/L).

$\mathrm{Na} \%=\frac{\mathrm{Na}^{+}+K^{+}}{\mathrm{Ca}^{2+}+\mathrm{Mg}^{2+}+\mathrm{Na}^{+}+K^{+}} \times 100$

$\mathrm{Na} \%$ criteria is widely used to ensure the groundwater suitability for agricultural irrigation. The irrigation water quality in the confined aquifer is categories as excellent $(6.9 \%)$, good $(31.03 \%)$, permissible $(34.48 \%)$, poor $(24.14 \%)$, and unsuitable $(3.45 \%)$ according to the $\mathrm{Na} \%$ index, while the samples in unconfined aquifer fall under excellent (21.74\%), good (34.78\%), and permissible (43.48\%) (Figs. 7 and 8). Also, the results showed that the sample categorized as unsuitable for irrigation use fall in middle part of study area (B06).

Soluble Sodium Percentage Soluble sodium percentage (SSP) is defined as in the Eq. 8 (Todd and Mays 1980), where all ions unit in milliequivalent per liter (meq/L).

$\mathrm{SSP}=\frac{\mathrm{Na}^{+}}{\mathrm{Ca}^{2+}+\mathrm{Mg}^{2+}+\mathrm{Na}^{+}} \times 100$
The variation of the SSP index in the confined and unconfined aquifer is 12.97-82.09 and 4.03-57.07, respectively. It is seen that the SSP of the confined and unconfined aquifers is high in the middle part of the map, which means that the water of wells located in this part is not suitable for irrigation (Figs. 7 and 8). According to the SSP index, the statistical results indicate that $68.97 \%$ and $86.96 \%$ of samples in the confined and unconfined aquifers categorise suitable for irrigation, while $31.03 \%$ and $13.04 \%$ are unsuitable for use, respectively.

Residual Sodium Carbonate Residual sodium carbonate (RSC) is defined as in the Eq. 9 (Richards 1954; Singh et al. 2013), where all ions unit in milliequivalent per liter (meq/L).

$\mathrm{RCS}=\left(\mathrm{HCO}_{3}^{-}+\mathrm{CO}_{3}^{2-}\right)-\left(\mathrm{Ca}^{2+}+\mathrm{Mg}^{2+}\right)$

If the concentration of alkaline metals is less than the concentration of carbonate in irrigation water, the sodium ion would bind with excess carbonate to form $\mathrm{NaHCO}_{3}$ and subsequently impact the soil texture. Thus, the result of the relationship between alkaline metals and carbonate is used for rating groundwater quality for irrigation purposes. Table 10 and Figs. 7 and 8 show that the water quality of both aquifers for the whole area is tolerable except the D07 sample in the north part of map. The high value of RSC in water may be caused by presence sodium ion in the water in the form of sodium carbonate (Vesali Naseh et al. 2018).

Magnesium Hazard Magnesium hazard ( $\mathrm{MH})$ is defined as in the Eq. 10 (SZABOLCS 1964; Gowd 2005), where all ions unit in milliequivalent per liter (meq/L).

$\mathrm{MH}=\frac{\mathrm{Mg}^{2+}}{\mathrm{Ca}^{2+}+\mathrm{Mg}^{2+}} \times 100$

Generally, calcium and magnesium maintain the water stability condition. Increasing magnesium amount in irrigation water would negatively affect the soils, rendering them unfit for farming and declining the crop yield (Tiwari et al. 2017). Figures 7 and 8 and Table 10 show that all groundwater samples in the study area are categorized as good water and safe to crops except four samples, which are unacceptable for irrigation purposes. Three of them belong to the confined aquifer, namely B01, B13, and B19, and one sample (D01) belongs to the unconfined aquifer. All these samples are located in the middle part of the study area. 

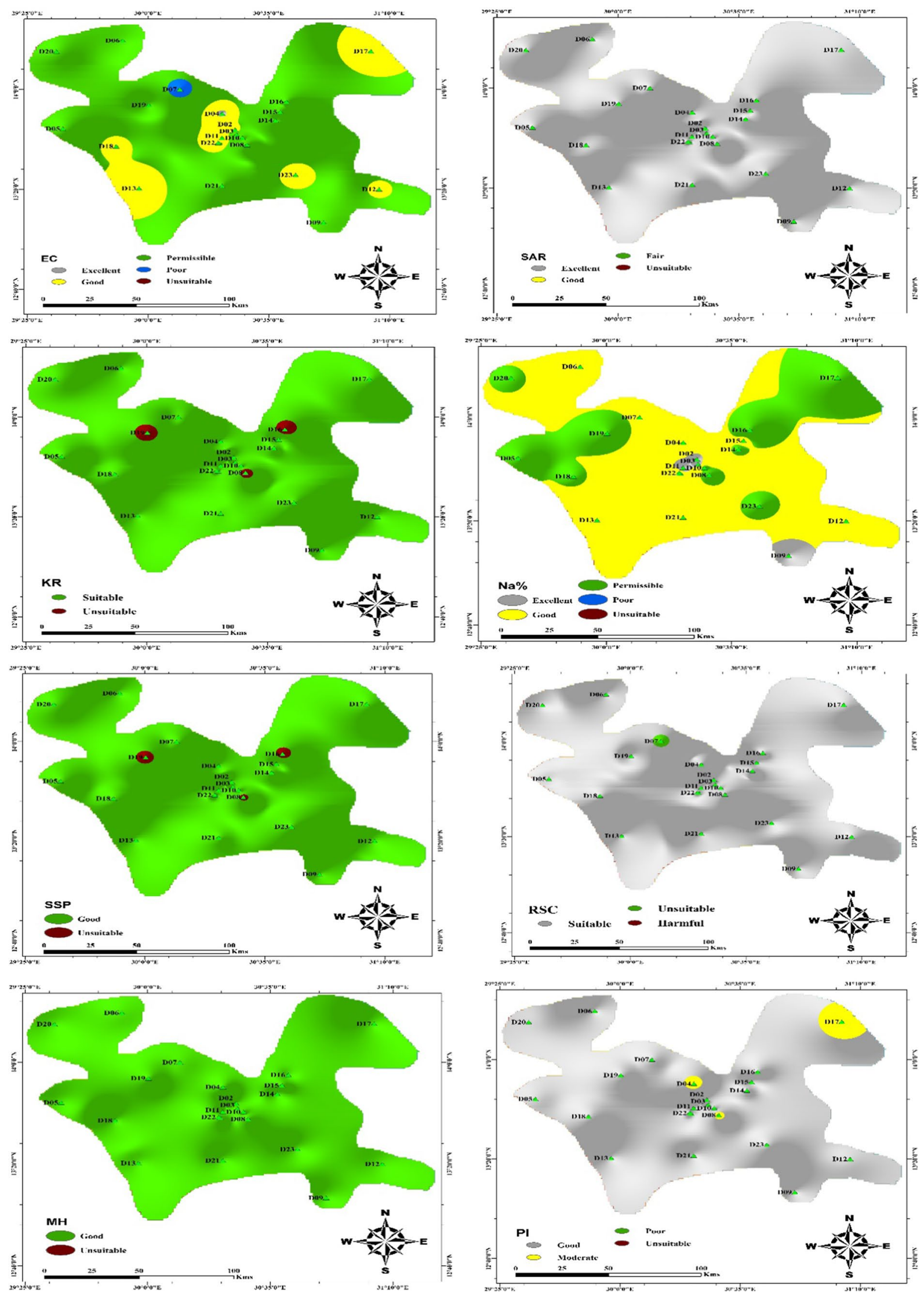

Fig. 8 Spatial distribution of GIS interpolation maps of the irrigation quality indices results (EC, SAR, KR, Na\%, SSP, RSC, MH, and PI) in unconfined aquifer 1 
Permeability Index Permeability index (PI) is defined as in the Eq. 11 (Singh et al. 2013), where all ions unit in milliequivalent per liter (meq/L).

$\mathrm{PI}=\frac{\mathrm{Na}^{+}+\mathrm{K}^{+}+\sqrt{\mathrm{HCO}_{3}^{-}}}{\mathrm{Ca}^{2+}+\mathrm{Mg}^{2+}+\mathrm{Na}^{+}+\mathrm{K}^{+}} \times 100$

The PI is a proper indicator to assess the effect of soil permeability caused by the deposition of bicarbonate of compounds such as sodium, calcium, and magnesium. The measured PI values for the confined and unconfined aquifers vary between 23.98 to 144.04 and 32.62 to $92.65 \mathrm{meq} / \mathrm{l}$, respectively. Based on the PI value, it is found from Figs. 7 and 8 that the water quality of all samples is suitable for irrigation use except the sample B29 in the confined aquifer. In the geostatistical evaluation analysis section, the findings indicate that the parameters of TDS, $\mathrm{Cl}^{-}, \mathrm{Na}^{+}, \mathrm{Ca}^{2+}, \mathrm{Mg}^{2+}$, $\mathrm{pH}$, and $\mathrm{HCO}_{3}{ }^{-}$are control the chemistry of groundwater. Therefore, the high value of PI is caused by these water variables suggesting that the natural weathering control the groundwater system.

Wilcox Diagrams The groundwater samples data are plotted on the Wilcox diagram (Wilcox 1955), which examines the overall influence of the salinity and sodium hazards for each location (Fig. 9). In terms of suitability for irrigation, the Wilcox diagram categorizes the water quality into 16 zones based on the effects of salinity and sodium. The salinity hazard $(\mathrm{C} \mu \mathrm{mhos} / \mathrm{cm})$ is divided into the low salinity $(\mathrm{C} 1,<250)$, medium $(\mathrm{C} 2,250-750)$, high $(\mathrm{C} 3,750-2250)$, and very high salinity $(\mathrm{C} 4,>2250)$, which are classified as good, moderate, poor, and very poor water, respectively (Bian et al. 2018). The sodium hazard (S $\mu \mathrm{mhos} / \mathrm{cm}) \mathrm{can}$ be divided into low sodium hazard $(\mathrm{S} 1,<10)$, medium $(\mathrm{S} 2$,
10-18), high (S3, 18-26), and very high sodium (S4,>26) hazard, which are referred to as good, moderate, poor, and very poor water quality, respectively (Bian et al. 2018).

Figure 9a revealed seven categories of irrigation water quality of confined aquifer: $6.9 \%$ samples in the $\mathrm{C} 1-\mathrm{S} 1$ zone (B27 and B29), 41.38\% in C2-S1 (B01-B5, B12, B13, B16, $\mathrm{B} 18, \mathrm{~B} 19, \mathrm{~B} 21$ and $\mathrm{B} 25), 3.45 \%$ in $\mathrm{C} 2-\mathrm{S} 2$ (B06), $37.93 \%$ in C3-S1 (B07-B09, B11, B14, B17, B20, B22, B24, B26 and $\mathrm{B} 28), 3.45 \%$ in $\mathrm{C} 3-\mathrm{S} 2$ (B23), 3.45\% in $\mathrm{C} 3-\mathrm{S} 3$ (B05), and $3.45 \%$ in $\mathrm{C} 4-\mathrm{S} 1$ (B10). Through Fig. 6a, it is seen that three samples (B05, B10, and B23) are considered harmful for irrigation use. The samples are located in the middle part of study area. Moreover, the pollution in these sites can originate from either natural or anthropogenic sources. It is also observed that the samples belonging to the confined aquifer fall in the zone of low (86.21\%), medium (10.34\%), and high (3.45\%) according to sodium hazard. Figure $9 \mathrm{~b}$ revealed four categories of irrigation water quality of unconfined aquifer: $4.35 \%$ in the $\mathrm{C} 1-\mathrm{S} 1$ zone (D04), $34.78 \%$ in $\mathrm{C} 2-\mathrm{S} 1$ (D02, D11-D13, D17, D18, D22, and D23), 56.52\% in C3-S1 (D01, D03, D06, D08, D10, D13-D17, D19-D21), and $4.35 \%$ in $\mathrm{C} 4-\mathrm{S} 1$ (D07). The results suggest that all samples belonging to the unconfined aquifer fall in the zone of low hazard of sodium (S1), with good (4.35\%), moderate $(34.78 \%)$, poor $(56.52 \%)$, and very poor water $(4.35 \%)$ related to salinity hazard.

IWQI Assessment Through Figs. 5, 6, 7, 9), it is seen that there are quite a number of variations in the results of individual irrigation indices, which motivates the proposal of a new index known as IWQI. The new approach takes a relatively more significant number of parameters into account to provide a comprehensive evaluation of ground water quality for irrigation use. The proposed IWQI is applied on the
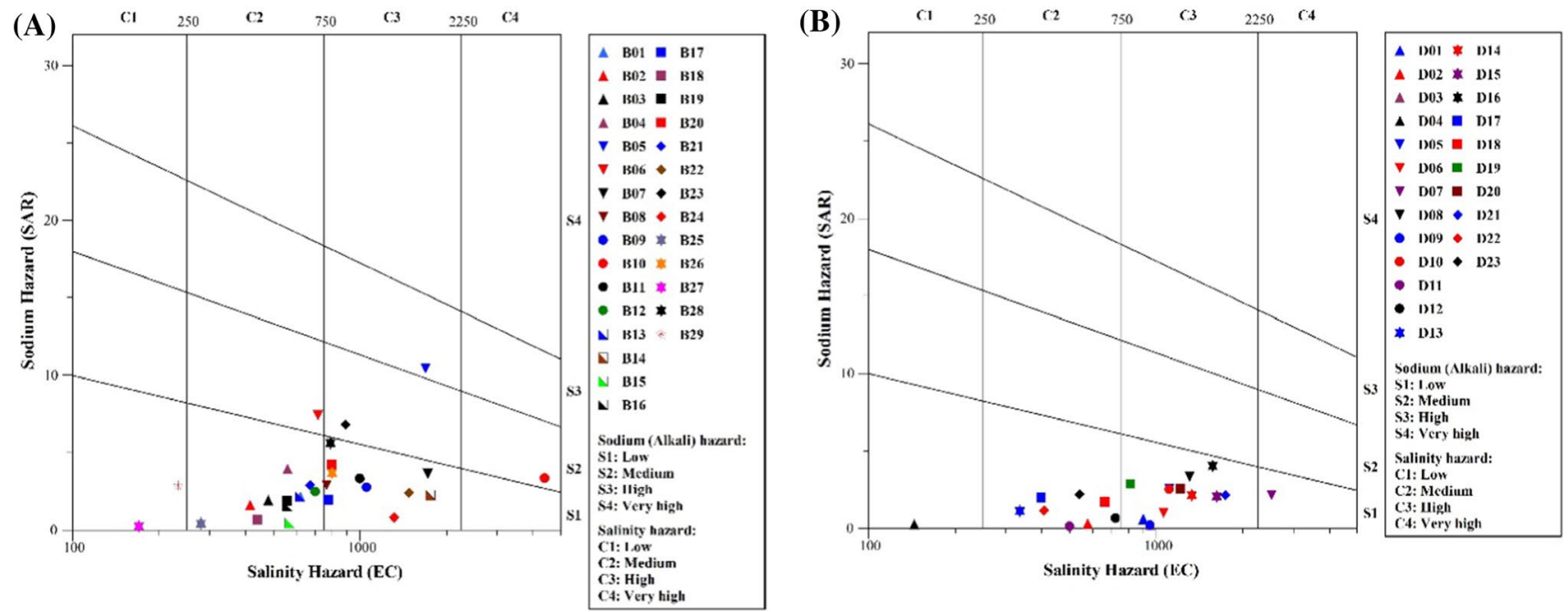

Fig. 9 Classification of irrigation water quality compared to the hazards of the salinity and sodium for (a) confined and (b) unconfined aquifers 
groundwater samples for both aquifers, and accordingly, the suitability for irrigation purposes is assessed. In this work, we developed a Microsoft Excel 2016-based code to compute the IWQI results. Table 9 shows the results of IWQI for all groundwater samples of both aquifers.

The IWQI values in the current study are derived by applying the water quality elements such as $\mathrm{pH}, \mathrm{Cl}, \mathrm{NO}_{3}$, EC, SAR, KR, Na\%, SSP, RSC, MH, and PI for each of the 52 groundwater samples used. The estimated values of IWQI vary from 17.98 to 121.65 and 19.08 to 85.14 (with mean 62.52 and 50.80) for confined and unconfined aquifers, respectively. The statistical results indicate that $3.45 \%$ of groundwater samples in the confined aquifer are excellent, $37.93 \%$ good, $31.03 \%$ moderate, $13.79 \%$ poor, and $13.79 \%$ of samples are very poor or unqualified for irrigation purposes (Table 10). For unconfined aquifer, about $4.35 \%$ of samples are excellent, $39.13 \%$ good, $43.48 \%$ moderate, and 13.04 are poor water (Table 10). The worst values of IWQI for confined aquifer are 121.65, 120.56, 114.47, and 104.02, which are found at station B06, B05, B23, and B29 and can be attributed to rocky weathering (natural origin). Based on the IWQI classification, the water quality in these stations is poor and unsuitable for irrigation use. For unconfined aquifer (shallow), at stations D08, D07, and D16, the IWQI values are 85.14.82.86, and 77.75, respectively, which are fairly good. The water quality of these samples can be linked to leaching of parameters from surface runoff like fertilizers and pesticides (anthropogenic origin).

The spatial distribution of IWQI clearly agrees with the spatial distribution of the parameters (Fig. 10). Our approach

Table 9 Main descriptive statistics of parameters and IWQI method in the studied irrigation water under different aquifer types in North Kurdufan

\begin{tabular}{lllrrlllllllrr}
\hline Aquifer & & $\mathrm{pH}$ & $\mathrm{Cl}$ & $\mathrm{NO}_{3}$ & $\mathrm{EC}$ & $\mathrm{SAR}$ & $\mathrm{KR}$ & $\mathrm{Na} \%$ & $\mathrm{SSP}$ & $\mathrm{RSC}$ & $\mathrm{MH}$ & $\mathrm{PI}$ & $\mathrm{IWQI}$ \\
\hline Confined $(N=29)$ & Min & 6.90 & 10.60 & 3.00 & 170 & 0.18 & 0.15 & 14.62 & 12.97 & -20.4 & 1.00 & 23.98 & 17.98 \\
& $\mathrm{Max}$ & 9.10 & 258.80 & 89.10 & 4400 & 7.39 & 4.58 & 82.81 & 82.09 & 1.85 & 78.04 & 144.04 & 121.65 \\
& Mean & 8.06 & 90.72 & 31.69 & 925 & 2.12 & 1.22 & 47.03 & 45.45 & -2.87 & 32.05 & 72.60 & 62.52 \\
& $\mathrm{SD}$ & 0.46 & 63.34 & 24.44 & 779 & 1.56 & 1.13 & 19.71 & 20.00 & 5.48 & 15.20 & 25.95 & 28.66 \\
Unconfined $(N=23)$ & Min & 8.00 & 12.05 & 1.86 & 144 & 0.08 & 0.04 & 6.30 & 4.03 & -5.72 & 24.91 & 32.62 & 19.08 \\
& Max & 9.40 & 124.07 & 47.33 & 2519 & 2.85 & 1.33 & 57.68 & 57.07 & 3.33 & 51.40 & 92.65 & 85.14 \\
& Mean & 8.58 & 55.79 & 17.64 & 978 & 1.16 & 0.58 & 34.18 & 32.80 & -1.21 & 40.00 & 62.64 & 50.80 \\
& $\mathrm{SD}$ & 0.32 & 36.34 & 11.70 & 536 & 0.77 & 0.38 & 15.62 & 16.43 & 1.78 & 6.76 & 16.31 & 18.78 \\
\hline
\end{tabular}

All parameters unit in Meq/l, except the $\mathrm{EC}(\mu \mathrm{mhos} / \mathrm{cm}), \mathrm{Cl}$ and $\mathrm{NO}_{3}$ in $(\mathrm{mg} / \mathrm{l})$ and $\mathrm{pH}$ (dimensionless)

Table 10 Rating of the groundwater samples utilized for irrigation based on the EC, SAR, KR, Na\%, SSP, RSC, MH, PI indices, and a new approach

\begin{tabular}{|c|c|c|c|c|c|c|c|c|c|}
\hline \multirow[t]{2}{*}{ Model } & \multirow[t]{2}{*}{ Range } & \multirow[t]{2}{*}{ Water Category } & \multicolumn{2}{|c|}{ Samples \% } & \multirow[t]{2}{*}{ Model } & \multirow[t]{2}{*}{ Range } & \multirow[t]{2}{*}{ Water Category } & \multicolumn{2}{|c|}{ Samples \% } \\
\hline & & & Confined & Unconfined & & & & Confined & Unconfined \\
\hline \multirow[t]{5}{*}{$\mathrm{EC}$} & $<250$ & Excellent & 6.90 & 4.35 & \multirow[t]{2}{*}{ SSP } & $<50$ & Good & 68.97 & 86.96 \\
\hline & $250-750$ & Good & 44.83 & 34.78 & & $>50$ & Unsuitable & 31.03 & 13.04 \\
\hline & $750-2000$ & Permissible & 44.83 & 56.52 & \multirow[t]{3}{*}{ RSC } & $<2.5$ & Suitable & 100 & 95.65 \\
\hline & $2000-3000$ & Poor & 0 & 4.35 & & $2.5-5$ & Unsuitable & 0 & 4.35 \\
\hline & $>3000$ & Unsuitable & 3.45 & 0 & & $>5$ & Harmful & 0 & 0 \\
\hline \multirow[t]{4}{*}{ SAR } & $0-10$ & Excellent & 100 & 100 & \multirow[t]{2}{*}{ MH } & $<50$ & Good & 89.66 & 95.65 \\
\hline & $10-18$ & Good & 0 & 0 & & $>50$ & Unsuitable & 10.34 & 4.35 \\
\hline & $18-26$ & Fair & 0 & 0 & \multirow[t]{4}{*}{ PI } & $<80$ & Good & 58.62 & 86.96 \\
\hline & $>26$ & Unsuitable & 0 & 0 & & 80-100 & Moderate & 24.14 & 13.04 \\
\hline \multirow[t]{2}{*}{$\mathrm{KR}$} & $<1$ & Suitable & 68.97 & 86.96 & & $100-120$ & Poor & 13.79 & 0 \\
\hline & $>1$ & Unsuitable & 31.03 & 13.04 & & $>120$ & Unsuitable & 3.45 & 0 \\
\hline \multirow[t]{5}{*}{$\mathrm{Na} \%$} & $0-20$ & Excellent & 6.90 & 21.74 & \multirow[t]{5}{*}{ IWQI } & $<25$ & Excellent & 3.45 & 4.35 \\
\hline & $20-40$ & Good & 31.03 & 34.78 & & $26-50$ & Good & 37.93 & 39.13 \\
\hline & $40-60$ & Permissible & 34.48 & 43.48 & & $51-75$ & Moderate & 31.03 & 43.48 \\
\hline & $60-80$ & Poor & 24.14 & 0 & & $76-100$ & Poor & 13.79 & 13.03 \\
\hline & $>80$ & Unsuitable & 3.45 & 0 & & $>100$ & Very poor & 13.79 & 0 \\
\hline
\end{tabular}



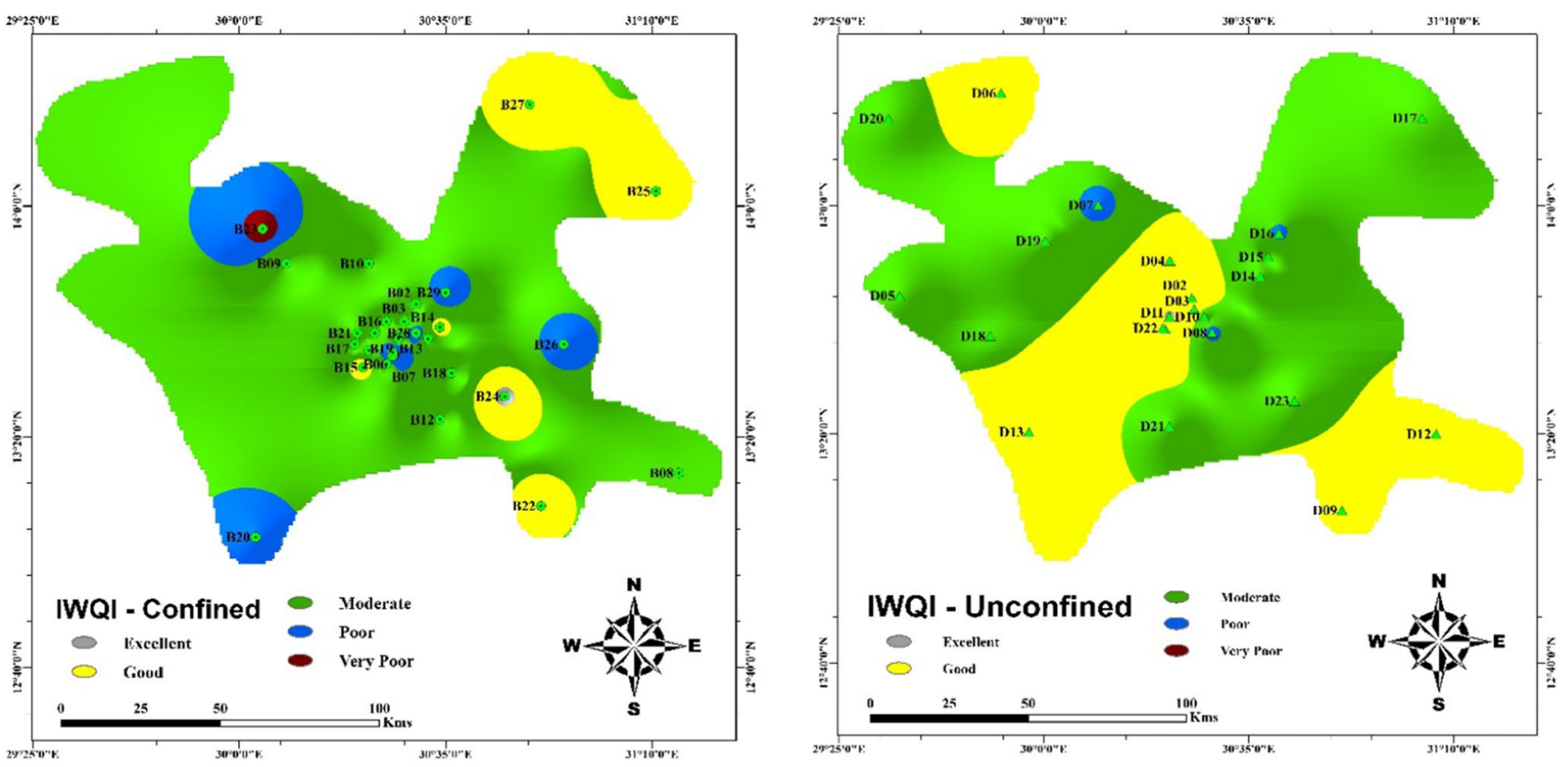

Fig. 10 Spatial distribution of GIS interpolation maps of the IWQI in the confined and unconfined aquifers

is also in harmony with the $\mathrm{KR}, \mathrm{Na} \%$, and SSP in terms of the worst samples for confined and unconfined aquifers, which are B06 and D08 samples, respectively. It is also found that the result of IWQI is similar to that of $\mathrm{KR}, \mathrm{Na} \%$, $\mathrm{SSP}$, and PI in terms of best sample for the confined aquifer (B24), and also in agreement with SAR, KR, Na\%, and SSP for the unconfined aquifer (D11). It can be seen from Fig. 10 that the IWQI for the confined aquifer is fairly high and very high in the middle part of the area. Besides, it noticed that the IWQI for the unconfined aquifer is low in the southern part, slightly high in the northern part, and relatively high in the middle part of the study area. It is obvious from these results that the groundwater of both aquifers in the southern portion of the study area has much better quality and acceptable for irrigation use than that of the north.

Conclusion The present study was conducted to develop a an effective way to evaluate groundwater quality for irrigation purposes in the case study of North Kurdufan State, Sudan. The new index was developed based on eleven irrigation water parameters. It is applied to set up the irrigation indices combined with AHP and ArcGIS technology to determine the weight of every index and zoning of the irrigation water quality level. AHP was applied to provide criteria and sort weight based on multiple criteria decision analysis tools (MCDA). Fifty-two groundwater samples were obtained from two aquifers and analyzed for their physicochemical characteristics. Geostatistical evaluation indicated that weathering of silicate with limited contribution from anthropogenic activities controls the chem- istry of the aquifer system. Also, the results showed that the ions $\left(\mathrm{Ca}^{2+}, \mathrm{Na}^{+}, \mathrm{Mg}^{2+}, \mathrm{Cl}^{-}\right.$, and $\left.\mathrm{SO}_{4}{ }^{2-}\right)$ are the major contributors in the geochemical process that regulates groundwater quality in the confined aquifer. Whereas, the $\left(\mathrm{Ca}^{2+}, \mathrm{Na}^{+}, \mathrm{Mg}^{2+}, \mathrm{Cl}^{-}, \mathrm{HCO}_{3}{ }^{-}, \mathrm{SO}_{4}{ }^{2-}\right.$, and $\left.\mathrm{NO}_{3}{ }^{-}\right)$are the major contributors in the geochemical process that regulates groundwater quality in the unconfined aquifer.

According to the results of irrigation indices and overall IWQI index, the majority of samples for both aquifers are admissible for irrigation purposes except for a few. Generally, irrigation water from the confined aquifer contains more chemical contaminants than those from the unconfined aquifer. It was also observed that the middle part of the study area is more contaminated compared to the rest. The proposed IWQI was compared with the existing indexing methods which are widely used in the literature, and the following conclusions are drawn;

- The spatial distribution of IWQI is in complete agreement with the parameters spatial distribution.

- This approach reduces the subjectivity at assign parameter weights and improves understanding of water quality classification.

- It is also noted that there are extensive variations in the results of existing irrigation evaluation indices.

It is expected that the method suggested in this paper may help in assessing irrigation water quality and helpful to the agricultural engineers, environmental managers in 
evaluation, monitoring, and control of the irrigation water system.

\section{Recommendations}

- From the results discussed hitherto, various remediation measures for irrigation water should be taken to reduce the possibility of salinity problems and soil degradation.

- Environmental attention, such as systematic quality control and adoption of water abstraction plan is crucial to guarantee sufficient protection for the aquifers.

- Continuous monitoring and the rigorous analysis of monitoring data are also necessary to conserve and preserve the quality of groundwater around this area.

- Beside high concentration of nitrates: Instituting regulations for limiting the excessive use of pesticides and fertilizers for agricultural, because surface water and groundwater are mostly overlapping, thus runoff can contaminate both.

- The study concluded that natural pollution is an essential source of pollution in the region due to over pumping from wells. Therefore, we recommend that rainwater harvesting work be carried out in the region for domestic and agricultural, as well as the construction of injection wells to feed underground reservoirs.

Author's contributions EE study conceptualization and formal analysis, $\mathrm{EE}$ investigation, and data collection, EE, AKM and YM wrote and prepared the original manuscript draft, EE prepared figures, EE, TH and AKM writing-review and editing, EE and TH supervision, project administration, and funding acquisition $\mathrm{TH}$. All authors helped to draft the manuscript. All authors read and approved the final version of the manuscript.

Funding This research was supported by the Sichuan Science and Technology Program (2019YFH0058).

\section{Declarations}

Competing interests Authors declare that they have no conflicting interests.

Open Access This article is licensed under a Creative Commons Attribution 4.0 International License, which permits use, sharing, adaptation, distribution and reproduction in any medium or format, as long as you give appropriate credit to the original author(s) and the source, provide a link to the Creative Commons licence, and indicate if changes were made. The images or other third party material in this article are included in the article's Creative Commons licence, unless indicated otherwise in a credit line to the material. If material is not included in the article's Creative Commons licence and your intended use is not permitted by statutory regulation or exceeds the permitted use, you will need to obtain permission directly from the copyright holder. To view a copy of this licence, visit http://creativecommons.org/licenses/by/4.0/.

\section{References}

Abdalla OA (2006) Aquifer systems in Kordofan, Sudan: Subsurface lithological model. South African J Geol 109:585-598. https:// doi.org/10.2113/gssajg.109.4.585

Ali HO, Whiteley RJ (1981) Gravity exploration for groundwater in the Bara basin, sudan. Geoexploration 19:127-141. https://doi.org/10. 1016/0016-7142(81)90025-9

Ayers RS, Westcot DW (1985) Water quality for agriculture. Food and Agriculture Organization of the United Nations Rome, Vol 29, p. 174.

Bian J, Nie S, Wang R, Wan H, Liu C (2018) Hydrochemical characteristics and quality assessment of groundwater for irrigation use in central and eastern Songnen Plain, Northeast China. Environ Monit Assess 190:1-16. https://doi.org/10.1007/ s10661-018-6774-4

Bikundia DS, Mohan D (2014) Major ion chemistry of the ground water at the Khoda Village, Ghaziabad. India Sustain Water Qual Ecol 3:133-150. https://doi.org/10.1016/j.swaqe.2014.12.001

Chadetrik R, Baldev S (2018) Suitability assessment of groundwater qquality for irrigation purpose: a case study. Int J Res Appl Sci Eng Technol 6:4863-4870. https://doi.org/10.22214/ijraset.2018. 4797

Dee N, Baker J, Drobny N, Duke K, Whitman I, Fahringer D (1973) An environmental evaluation system for water resource planning. Water Resour Res 9:523-535. https://doi.org/10.1029/WR009 i003p00523

Dinius SH (1972) Social accounting system for evaluating water resources. Water Resour Res 8:1159-1177. https://doi.org/10. 1029/WR008i005p01159

Eldaw E, Huang T, Elubid B, Khalifa Mahamed A, Mahama Y (2020) A novel approach for indexing heavy metals pollution to assess groundwater quality for drinking purposes. Int J Environ Res Public Health 17:1245. https://doi.org/10.3390/ijerph17041245

Fragaszy S, Closas A (2016) Cultivating the desert: Irrigation expansion and groundwater abstraction in Northern State, Sudan. Water Altern 9:139-161

Gowd SS (2005) Assessment of groundwater quality for drinking and irrigation purposes: a case study of Peddavanka watershed, Anantapur District, Andhra Pradesh, India. Environ Geol 48:702-712. https://doi.org/10.1007/s00254-005-0009-Z

Hao J, Zhang Y, Jia Y, Wang H, Niu C, Gan Y, Gong Y (2017) Assessing groundwater vulnerability and its inconsistency with groundwater quality, based on a modified DRASTIC model: a case study in Chaoyang District of Beijing City. Arab J Geosci 10:144. https://doi.org/10.1007/s12517-017-2885-4

Horton RK (1965) An index number system for rating water quality. $J$ Water Pollut Control Fed 37:300-306

Javanbarg MB, Scawthorn C, Kiyono J, Shahbodaghkhan B (2012) Fuzzy AHP-based multicriteria decision making systems using particle swarm optimization. Expert Syst Appl 39:960-966. https://doi.org/10.1016/j.eswa.2011.07.095

Karakuş CB (2020) Evaluation of water quality of Kızılırmak River (Sivas/Turkey) using geo-statistical and multivariable statistical approaches. Environ Dev Sustain 22:4735-4769. https://doi.org/ 10.1007/s10668-019-00472-8

Kelley WP (1941) Permissible composition and concentration of irrigation water. Trans Am Soc Civ Eng 106:849-855. https://doi.org/ 10.1061/TACEAT.0005384 
Kim M, Kim Y, Kim H, Piao W, Kim C (2016) Enhanced monitoring of water quality variation in Nakdong River downstream using multivariate statistical techniques. Desalin Water Treat 57:1250812517. https://doi.org/10.1080/19443994.2015.1049963

Kumar M, Ramanathan AL, Rao MS, Kumar B (2006) Identification and evaluation of hydrogeochemical processes in the groundwater environment of Delhi, India. Environ Geol 50:1025-1039. https:// doi.org/10.1007/s00254-006-0275-4

Mena-Rivera L, Salgado-Silva V, Benavides-Benavides C, Coto-Campos JM, Swinscoe TH (2017) Spatial and seasonal surface water quality assessment in a tropical urban catchment: Burío River. Costa Rica Water (switzerland) 9:558. https://doi.org/10.3390/ w9080558

Merouche A, Selvam S, Imessaoudene Y, Maten CN (2020) Assessment of dam water quality for irrigation in the northeast of catchment Cheliff-Zahrez, Central Algeria. Environ Dev Sustain 22:5709-5730. https://doi.org/10.1007/s10668-019-00447-9

Mostafazadeh-Fard, B., Heidarpour, M., Aghakhani, A., \& Feizi, M. (2008) Effects of leaching on soil desalinization for wheat crop in an arid region. Plant, Soil Environ 54:20-29. https://doi.org/ 10.17221/2780-pse

Murmu P, Kumar M, Lal D, Sonker I, Singh SK (2019) Delineation of groundwater potential zones using geospatial techniques and analytical hierarchy process in Dumka district, Jharkhand. India Groundw Sustain Dev 9. https://doi.org/10.1016/j.gsd.2019.100239

Nematollahi MJ, Ebrahimi P, Razmara M, Ghasemi A (2016) Hydrogeochemical investigations and groundwater quality assessment of Torbat-Zaveh plain, Khorasan Razavi, Iran. Environ Monit Assess 188:1-21. https://doi.org/10.1007/s10661-015-4968-6

Nemčić-Jurec J, Singh SK, Jazbec A, Gautam SK, Kovač I (2019) Hydrochemical investigations of groundwater quality for drinking and irrigational purposes: two case studies of KoprivnicaKriževci County (Croatia) and district Allahabad (India). Sustain Water Resour Manag 5:467-490. https://doi.org/10.1007/ s40899-017-0200-X

Prati L, Pavanello R, Pesarin F (1971) Assessment of surface water quality by a single index of pollution. Water Res 5:741-751. https://doi.org/10.1016/0043-1354(71)90097-2

Ribeiro L, Paralta E, Nascimento J, Amaro S, Oliveira E, Salgueiro AR (2002) A Agricultura e a delimitação das zonas vulneráveis aos nitratos de origem agrícola segundo a directiva 91/676/CE. grupo. us.es/ciberico/archivos_acrobat/sevilla3ribeiro.pdf.

Richards LA (1954) Diagnosis and improvement of saline and alkali soils, vol. 78, No. 2, p. 154. LWW

Saaty TL (1980) Fundamentals of decision making and priority theory with analytical hierarchical process Vol VI. In: Sharma JC, Prasad J, Saha SK, Pande LM (eds) Watershed prioritization based sediment yield index East part Don Val using RS. GIS Indian J Soil Conserv 29:713.

Sahani N (2020) Application of analytical hierarchy process and GIS for ecotourism potentiality mapping in Kullu District, Himachal Pradesh, India. Environ Dev Sustain 22:6187-6211. https://doi. org/10.1007/s10668-019-00470-w

Sashikkumar MC, Selvam S, Karthikeyan N, Ramanamurthy J, Venkatramanan S, Singaraja C (2017) Remote sensing for recognition and monitoring of vegetation affected by soil properties. J Geol Soc India 90:609-615. https://doi.org/10.1007/ s12594-017-0759-8

Selvam S (2015) A preliminary investigation of lithogenic and anthropogenic influence over fluoride ion chemistry in the groundwater of the southern coastal city, Tamilnadu, India. Environ Monit Assess 187:1-20. https://doi.org/10.1007/s10661-015-4326-8

Singaraja C, Chidambaram S, Srinivasamoorthy K, Anandhan P, Selvam S (2015) A study on assessment of credible sources of heavy metal pollution vulnerability in groundwater of Thoothukudi
Districts, Tamilnadu, India. Water Qual Expo Heal 7:459-467. https://doi.org/10.1007/s12403-015-0162-x

Singh S, Singh C, Kumar K, Gupta R, Mukherjee S (2009) Monitorování podzemní vody v čase a v prostoru pomocí multivariačních statistických metod v oblasti Bareilly, Uttar Pradesh, India. J Hydrol Hydromechan 57:45-54. https://doi.org/10.2478/ v10098-009-0005-1

Singh J, Mishra NS, Banerjee S, Sharma YC (2011) Comparative studies of physical characteristics of raw and modified sawdust for their use as adsorbents for removal of acid dye. BioResources 6:2732-2743. https://doi.org/10.15376/biores.6.3.2732-2743

Singh AK, Bharati RC, Pedpati A (2013) An assessment of faba bean (Vicia faba L.) current status and future prospect. African J Agric Res 8:6634-6641. https://doi.org/10.5897/AJAR2013.7335

Singh S, Ghosh NC, Krishan G, Galkate R, Thomas T, Jaiswal RK (2015) Development of an Overall Water Quality Index (OWQI) for Surface Water in Indian Context. Curr World Environ 10:813822. https://doi.org/10.12944/CWE.10.3.12

Singh S, Ghosh NC, Gurjar S, Krishan G, Kumar S, Berwal P (2018a) Index-based assessment of suitability of water quality for irrigation purpose under Indian conditions. Environ Monit Assess 190:29. https://doi.org/10.1007/s10661-017-6407-3

Singh SK, Laari PB, Mustak SK, Srivastava PK, Szabó S (2018b) Modelling of land use land cover change using earth observation datasets of Tons River Basin, Madhya Pradesh, India. Geocarto Int 33:1202-1222. https://doi.org/10.1080/10106049.2017.1343390

Sutadian AD, Muttil N, Yilmaz AG, Perera BJC (2016) Development of river water quality indices-a review. Environ Monit Assess 188:1-29. https://doi.org/10.1007/s10661-015-5050-0

Szabolcs I (1964) The influence of irrigation water of high Sodium Carbonate content on soils. Agrokémia és Talajt 13:237-246. http://real.mtak.hu/id/eprint/96046

Tiwari AK, Singh AK, Singh AK, Singh MP (2017) Hydrogeochemical analysis and evaluation of surface water quality of Pratapgarh district, Uttar Pradesh, India. Appl Water Sci 7:1609-1623. https:// doi.org/10.1007/s13201-015-0313-z

Todd DK, Mays LW (1980) Groundwater hydrology. Wlley, New York, p 535

Venkatramanan S, Chung SY, Selvam S, Lee SY, Elzain HE (2017) Factors controlling groundwater quality in the Yeonjegu District of Busan City, Korea, using the hydrogeochemical processes and fuzzy GIS. Environ Sci Pollut Res 24:23679-23693. https://doi. org/10.1007/s11356-017-9990-5

Vesali Naseh MR, Noori R, Berndtsson R, Adamowski J, Sadatipour E (2018) Groundwater pollution sources apportionment in the ghaen plain. Iran Int J Environ Res Public Health 15:172. https://doi.org/ 10.3390/ijerph15010172

Walski TM, Parker FL (1974) Consumers water quality index. ASCE J Env Eng Div 100:593-611. https://doi.org/10.1061/JEEGAV. 0000184

Whiteman AJ (1971) The Geology of the Sudan Republic. Clarendon Press, Oxford. https://doi.org/10.2307/3887142

WHO G (2011) Guidelines for drinking-water quality.** 216:303-304.

Wilcox L (1955) Classification and Use of Irrigation Waters. Department of Agriculture, United States (No. 969).

Wu H, Qian H, Chen J, Huo C (2017) Assessment of Agricultural Drought Vulnerability in the Guanzhong Plain, China. Water Resour Manag 31:1557-1574. https://doi.org/10.1007/ s11269-017-1594-9

Zhang Z, Liu X, Yang S (2009) A note on the 1-9 scale and index scale in ahp. In: International conference on multiple criteria decision making. Springer, Berlin, Heidelberg, pp. 630-634. https://doi. org/10.1007/978-3-642-02298-2_92

Publisher's Note Springer Nature remains neutral with regard to jurisdictional claims in published maps and institutional affiliations.

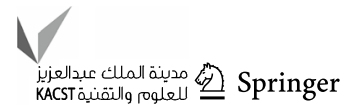

